\title{
Non-Timber Forest Products in Brazil: A Bibliometric and a State of the Art Review
}

\author{
Thiago Cardoso Silva *®D, Emmanoella Costa Guaraná Araujo, Tarcila Rosa da Silva Lins $₫$, \\ Cibelle Amaral Reis, Carlos Roberto Sanquetta and Márcio Pereira da Rocha $₫$
}

Department of Forestry Engineering and Technology, Federal University of Paraná, 80.210-170 Curitiba, Brazil; manuguarana@ufpr.br (E.C.G.A.); tarcila.lins@ufpr.br (T.R.d.S.L.); cibelle.reis@ufpr.br (C.A.R.);

sanquetta@ufpr.br (C.R.S.); mprocha@ufpr.br (M.P.d.R.)

* Correspondence: thiago.cardoso@ufpr.br; Tel.: +55-8199-956-6178

Received: 4 July 2020; Accepted: 22 August 2020; Published: 2 September 2020

\begin{abstract}
Non-timber forest products (NTFPs) are a consolidated source of income and acquisition of inputs from forest environments. Therefore, the objective of this work was to carry out a collection of publications on NTFPs in Brazil, until 2019, available in the Scopus database, presenting a bibliometric review and the state of the art of this theme from the evaluation of these publications, discussing the challenges of Brazilian legislation on NTFPs. After screening the articles of interest, 196 documents were evaluated, in which they were observed institutions and authors, analyzing networks of citations and terms used, areas of forest sciences and sciences that encompass the most explored biomes and the most studied species. The results showed that the concern to research on NTFPs in Brazil began in the 1990s, with an increase in the number of publications over the years. Besides that, the research on NTFPs is multidisciplinary, with emphasis on the areas of Agricultural and Biological Sciences and Environmental Science. For better regulation of the process of exploration and management of NTFPs in Brazil, the need to create specific legislation that takes into account factors such as the phytogeographic domain the explored area, producing species, and the products and co-products obtained was observed.
\end{abstract}

Keywords: natural products; forest production; forest products market; environmental legislation; forest management; extractivism

\section{Introduction}

The harvesting of wood in native forests has become a high impact activity in all ecosystems, representing a consolidated economic activity in the world forest sector, often leaving aside the scientific development that new products could bring. Considering the technological development that involves natural resources, the study of non-timber forest products (NTFPs) for their better use, makes them an important source of raw material that can be exploited in forest ecosystems. Thus, the use of the ecological and socioeconomic potential of the forest constitutes an important strategy for the application of efficient management systems for these resources, aiming at the best form of use, culminating in sustainable development [1]. In this sense, biodiversity is the main responsible for the generation of new products and co-products.

NTFPs are the most utilized term referring to this kind of produce (non-wood forest products and minor forest products are some utilized denominations), some of those terminologies have a local legal definition, but there is no consolidated formal elucidation with global acceptance. A recent FAO analysis on such problematic suggests that it is unlikely that a single universal term and definition would be coined and globally accepted due to "cultural and contextual differences regarding how these products are perceived in different countries/regions and by different entities" [2]. This fact could 
lead to inconsistencies in data collection, processing, and analysis, which have a direct impact on the development of specific regulations and policies.

Historically, NTFPs are responsible for reducing poverty and encouraging conservation, ensuring an improvement in the quality of life of populations living in forest environments [3]. Brazil has a great diversity of natural resources, which favors the market for products related or not to wood, this activity being of paramount importance with regards to the social, economic, and political aspects of the country. In this way, extractivism has stimulated the creation of numerous national conservation units for sustainable use in recent years.

The regularization of the exploitation of natural resources is based on the application of specific laws for NTFPs. Despite being widely explored in Brazil, there is still no specific legislation to manage the extraction and commercialization of these products, finding definitions and some regulations in federal laws n. 11.284/2006 and n. 12.651/2012, known as Public Forest Management Law and New Forest Code, respectively. In them, there is some regulation concerning the exploitation of new products in forests managed by the Government or in areas of private properties, mainly for extractive activities $[4,5]$. Therefore, the creation of specific legislation to regularize this activity is essential to determine the best way to manage these resources.

Despite not having a concept determined by Brazilian federal law, in general, NTFPs are defined as substances, materials or goods of plant or animal origin, extracted from natural resources without the need to cut down trees, as well as the inclusion of social and environmental services, such as the conservation of genetic material and the carbon stock [6,7]. Furthermore, these resources can be extracted from natural forests or planted.

One way of gathering data referring to a certain context is the realization of the state of the art, in which the assimilation of scientific sources occurs, through the literature review and interpretive development of pre-existing data. The state of the art can be constructed from a bibliometric analysis, which presents a quantitative analysis of the information. Thus, through a database, keywords are used to search for texts related to the theme. Subsequently, these data are grouped by bibliometric indicators and their results are displayed in graphs and statistics, according to the knowledge areas to be evaluated.

It is observed in the literature that the records associated with the exploitation of NTFPs become uncertain, considering that a large part of this activity is not documented, remaining out of statistics. Thus, without this regularization, it becomes more difficult to implement a sustainable management system for these resources, which, as for timber products, overexploitation can cause environmental imbalance. Therefore, the objective of this work was to carry out a collection of publications on non-timber forest products in Brazil, until 2019, available in the Scopus database, presenting a bibliometric review and the state of the art of this theme from the evaluation of these publications, discussing the challenges of Brazilian legislation on non-timber forest products.

\section{Materials and Methods}

\subsection{Bibliometric Review}

To carry out the bibliometric evaluation on non-timber forest products in Brazil, an analysis of the publications on this topic was applied. The data used in this study were obtained only from the Scopus database, released by Relx Group. For this, publications have sought that address the theme, using the terms "non-timber forest product" and "Brazil" in titles, abstracts, and keywords, ensuring that the researched literature is fully aligned with the theme. The search sequence was as follows: TITLE-ABS-KEY ("non-timber forest product") ALL (Brazil). As they are important works in Brazil, the respective terms in Portuguese were also applied. In this review, all the works carried out until 2019 were evaluated. No cross-validation with any other databased was performed.

From the research carried out using the terms Scopus, 444 publications returned as a result. After identifying all of them, they were accessed from Google Scholar or the respective indexing portal. 
Subsequently, each publication was read, with a screening of works that evaluated non-timber forest products in Brazil. The selection criteria were: 1-works carried out in Brazilian phytogeographic domains; 2-the study area was in Brazilian territory; 3 - the species used are native to Brazil; and 4 -the works evaluated non-timber forest products. Only works that met these four criteria were selected for the following analyzes.

After being classified, the following parameters were identified in each publication: a-year of publication; $b$-identification, the institution of affiliation and nationality of the authors; $c$ - the creation of a map indicating the distribution of authors affiliations' institutions in Brazilian territory, using the ArcGIS version 10.5 program; $\mathrm{d}$-the creation of a network of interconnection clusters between authors, using the VOSviewer version 1.6.15 program; e-the creation of a network of interconnection clusters between the main words present in the titles of the works, also through VOSviewer; $f$-agencies and institutions that financed the works; g-publications' journals; $\mathrm{h}$-the type of publication per document; $i$-areas of science in which the works were inserted, according to Scopus classification; and $j-$ areas of forestry sciences in which the works were inserted. These data were tabulated using Microsoft Office Excel 365 Home, where graphs were also made for each parameter.

\subsection{State of the Art}

From the selected documents, a systematic review was carried out to elaborate on the state of the art, to determine which phytogeographic domains present the greatest potential for the use of products and co-products in the Brazilian territory, generating a database on the forest species studied in these researches. Besides, a review was made of the importance and challenges of legislation for the better exploitation of NTFPs in Brazil.

\section{Results and Discussion}

\subsection{Bibliometric Review}

After being classified according to the criteria used in this review, 196 useful publications were identified, which became the object of study in this work. According to the type of document in these publications (Figure 1), 95.9\% are articles and reviews, published according to the importance of research. The other types of publications were selected due to the relevance of the research and the respective results.

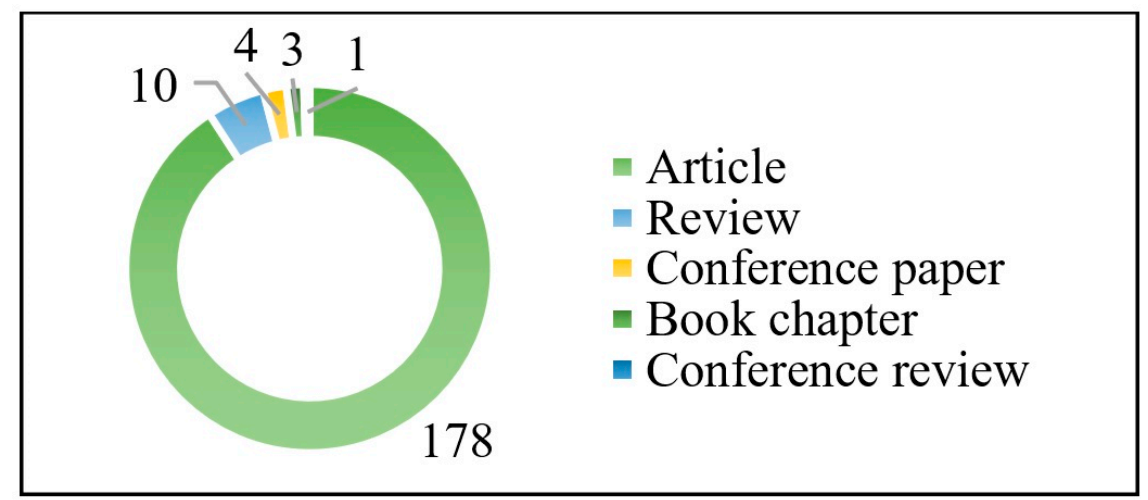

Figure 1. The number of publications on non-timber forest products in Brazil by types of documents, until 2019.

Those categories were automatically defined by the Scopus, which has classified the publications according to its structure. Articles are publications developed by a defined methodology, by which the authors acquired their results, furthermore, it exhibits and discusses ideas, methods, and techniques. Moreover, reviews are considered as publications that aim to discuss subjects explored by other authors, gathering information about specific matters by executing a review concerning current literature on the 
subject. Book chapters are those which take part in bibliographic compilations. Finally, the conference publications are scientific works propound in scientific conferences that could be submitted as full manuscript as paper or review.

Then, these publications were evaluated, and it was observed that the first work on the topic was published in 1992. On that matter, the Scopus database has records back to publications from the 18th century, but it does not cover all the publications because not all scientific journals and periodicals are indexed in its database. Hence, the publications that match the parameters established in this review registered on this platform that are relevant are being published since the early 1990s which do not mean that those are the first literature registered on the matter in the country.

Since its colonization by the Portuguese, numerous naturalists studied the Brazilian wildlife, resulting in their descriptions and use reports, with highlights for medicinal purposes. The NTFPs have a strong relationship with the country economy through its history: while a colony, the cocoa corresponded for almost all the exportations of the country; between 1850 and 1920 was the Amazon rubber boom by the extraction of the Hevea brasiliensis latex, a commodity commercialized worldwide with a second boom during the World War II; between 1920 and 1960 the Aniba rosaeodora essential oil was largely explored for the cosmetic industry and in the late decades various NTFPs are extracted for medicinal, cosmetic and nutritional purposes, such as Stryphnodendron adstringens, Copaifera sp., and Bertholletia excelsa [8]. Thus, since the late half of the 19th century, there are a relevant number of technical reports about wood properties and characterization as well as investigation of NTFPs, especially regarding medicinal purposes.

As for the years of publication (Figure 2), it was observed that the greatest peak of research related to the term non-timber forest products in Brazil, it occurred between 2010 and 2014, in which the highest number of publications was recorded (24). Some years have not registered any publication on the topic of interest in this review, being them 1993, 1994, 1995, 1998, 1999, and 2000. When the evaluation was carried out for decades, there was an expressive growth among the records, in which the decade of 1990 presented $4.6 \%$ of publications; in the 2000s, $21.9 \%$ were registered, an increase of $4.8 \mathrm{x}$; and in the decade of 2010 the largest number of publications was observed, $73.5 \%$, representing an increase of $3.3 x$ more publications than the previous decade.

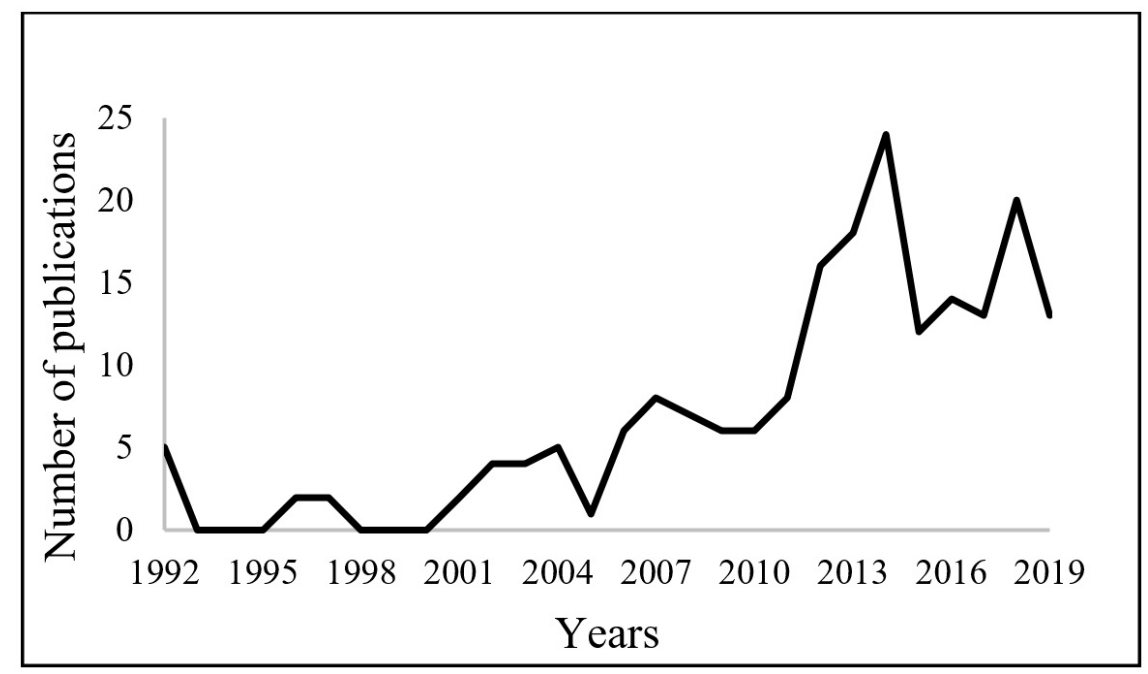

Figure 2. Publications on non-timber forest products in Brazil until 2019 per year.

When evaluating the most used terms in the titles of the works (Figure 3), 19 words stand out, being the main five: 1 -Brazil, also observing the presence of its equivalent in the Portuguese language, Brasil; 2-non timber forest product; 3-Brazilian amazon; 4-management; and 5-Amazônia, also observing the presence of its English equivalent, Amazon. 


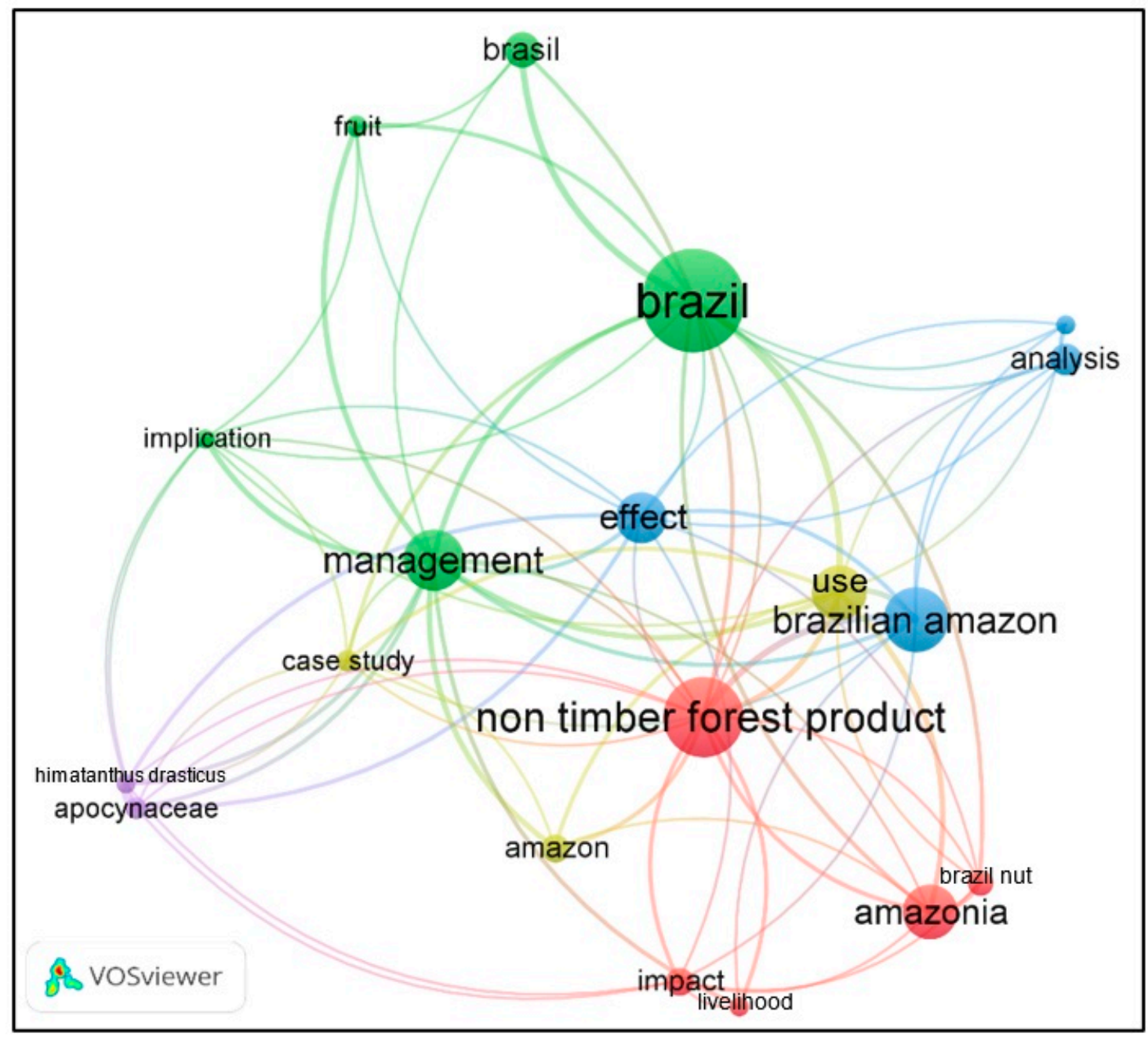

Figure 3. Interconnection network between the most used terms in the titles of publications on non-timber forest products in Brazil until 2019.

From Figure 3, the presence of some groups of words is observed, defined according to: 1—the location of the study, in the case of the terms Brazil/Brasil, Brazilian Amazon and Amazon/Amazonia, showing that studies in the Amazonian region are very important among the analyzed publications; 2-the product evaluated in the research, whether general terms such as fruit, or more specific, such as the product brazil nut, the family Apocynaceae and the species Himatanthus drasticus; and 3-the form of application and exploitation of the products, as observed by the use of the expressions management, effect, use, impact, analysis, implication, case study, and livelihood.

In these publications, 147 authors participated. As for their gender, the results are balanced, with $53.06 \%$ male and $46.94 \%$ female. Among the authors, 17 were classified as having the largest number of published works, with four or more publications (Figure 4). These 17 authors concentrate $46.5 \%$ of the publications on the theme, therefore they are considered the most relevant in the area.

Identifying the authors who publish on a given subject is one of the main points of a bibliometric review since highlighting them contributes to facilitating the gathering of databases concerning the subject of their research. On NTFPs, in particular, those bibliometric reviews can detect who the main specialists for each product are, thus leading future researches to references studies on this topic. 


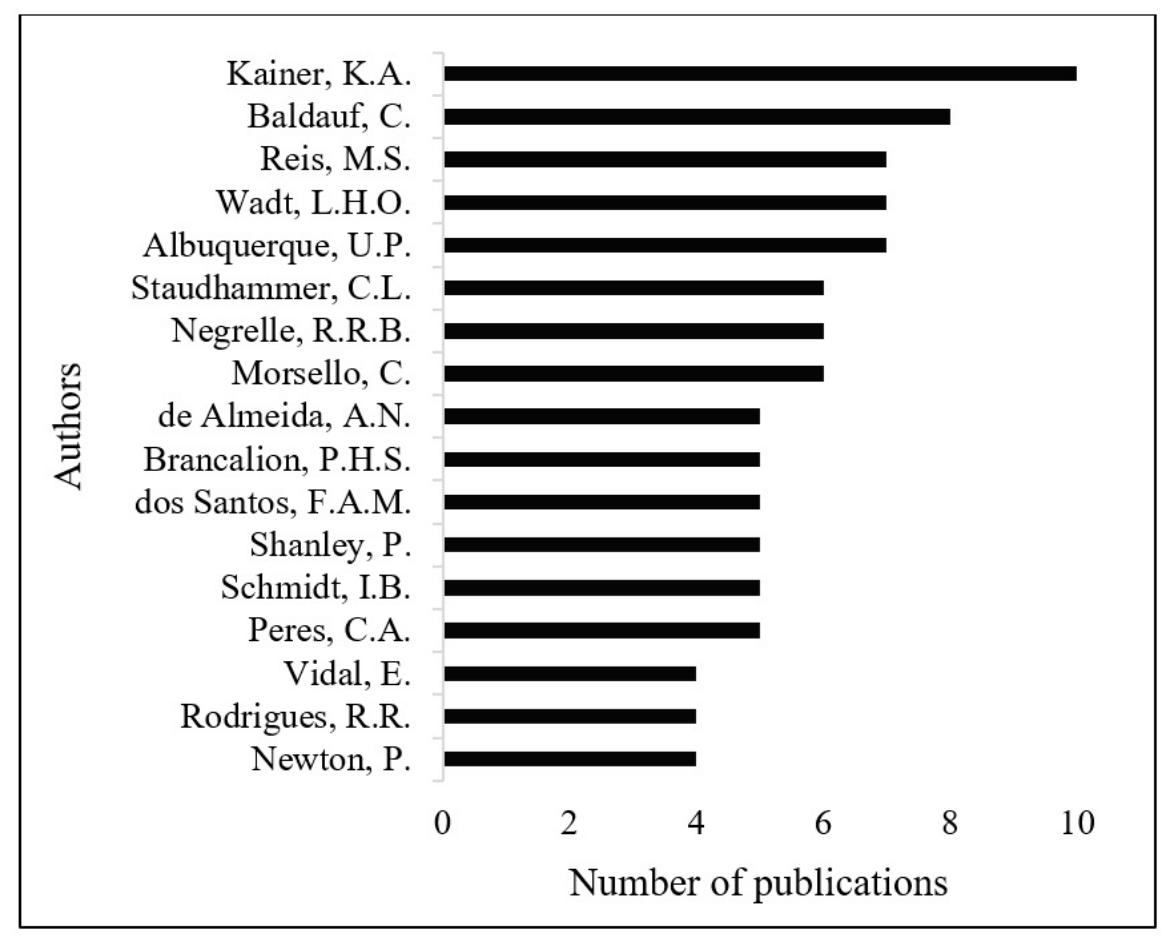

Figure 4. The number of publications by the 17 authors with the largest publications on non-timber forest products in Brazil until 2019.

Analyzing their publications, Kainer and Wadt have as their main focus the study of Amazonian forest resources, mainly due to the species Bertholletia excelsa, responsible for the production of Brazil nuts, and Carapa guianensis, popularly known as andiroba. As for Reis, the study area is in the Atlantic Forest, with a focus on research on the species Araucaria angustifolia and Euterpe edulis. Baldauf stands out in the study of the species Himatanthus drasticus (Apocynaceae), in a Cerrado environment. Albuquerque, on the other hand, presents the semi-arid regions of Northeast Brazil as its main publication network. It is observed that at first, the works appear to be well distributed in Brazilian biomes, but it does not happen that way. Most of the research is carried out in the Amazon, showing that although well distributed, the authors are publishing more about this biome, leaving out other products. It is also possible to observe that this theme is democratic and comprehensive since the authors have a great diversity of non-wood products with productive potential and which have some attributes for research.

As the reference authors, they can generate trends for these researches, causing the other researchers to help build a database on certain key products and leave the others aside. By becoming a reference on the theme, these authors contribute a lot to the development of future research, since they are at the base of the productive chain of publications on NTFPs. It is necessary, therefore, to diversify the focus that these authors gave to these products and to apply or adapt the methodologies for the other species. The knowledge gaps are in the non-exploitation of certain species precisely because they are not in the central focus of the researchers or have no confirmed use. However, the tendency is for products that are not so well known to become popular from the proof of their potential use, bringing quality and diversity in the economic exploitation of natural products.

Although Kainer is the author with the largest number of publications, she is not part of the main network of authors on the topic (Figure 5A), constituting one of the secondary networks, together with Wadt. The main network includes the authors Baldauf, Reis, Albuquerque, and Schmidt (Figure 5B), so, it is assumed that the main network is based on the Impact Factor (IF) of the journal where de works are being published, higher the IF higher will be the relevance of the study and consequently the relevance of the authors. 


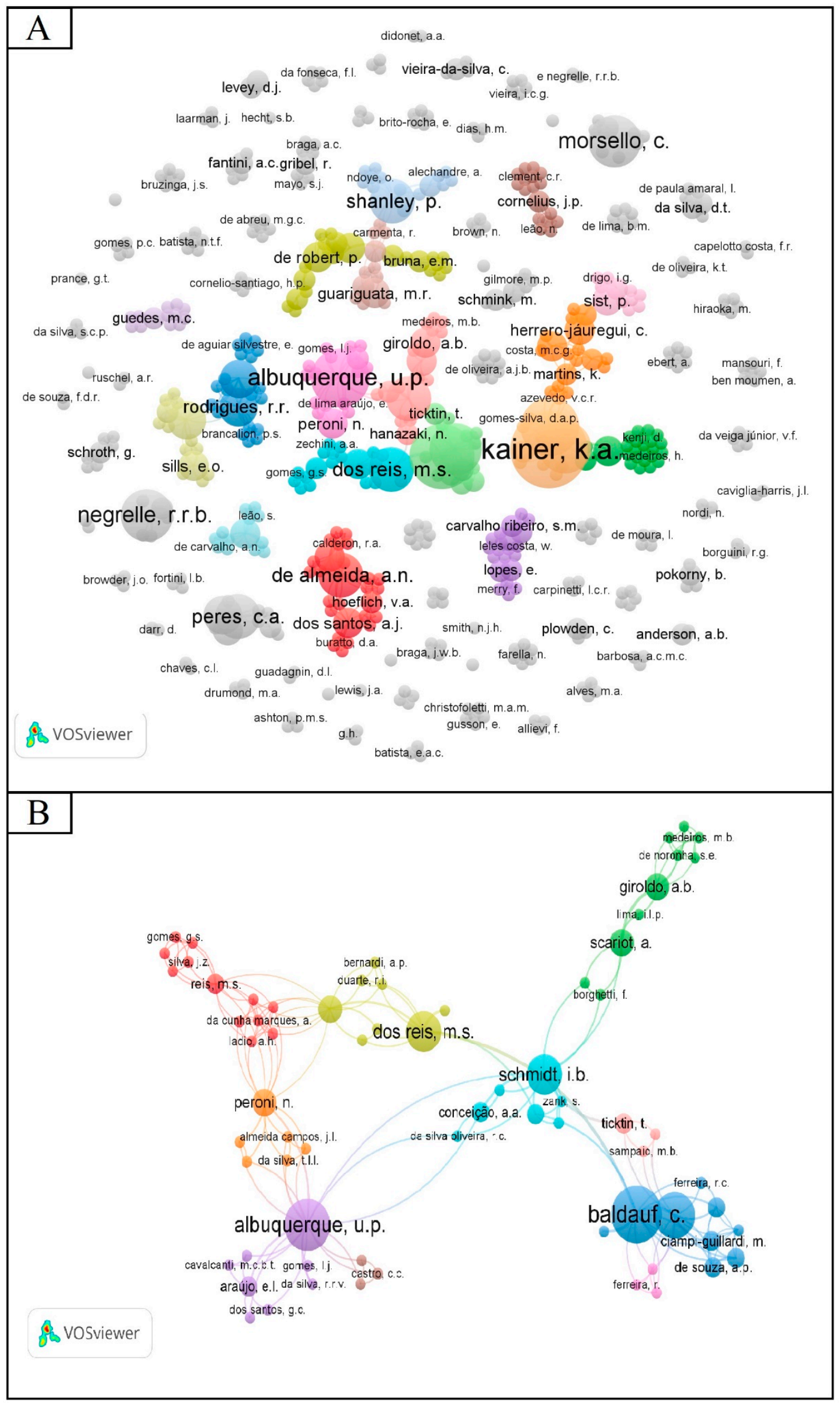

Figure 5. Clusters of interconnection publications between all authors (A) and main cluster (B). 
From the authors' data, it was identified that they are affiliated with 153 institutions, 79 of which are Brazilian (52.3\%) and 72 are international (47.7\%). Evaluating the affiliation institutions according to the occurrence in the different Brazilian geographic regions, or outside the national boundaries (Figure 6), the North region stands out, mainly linked to the exploitation of Amazon resources and the Southeast region, where institutions are present highly relevant teaching in the country, being responsible mainly for research in the Atlantic Forest and the Cerrado.

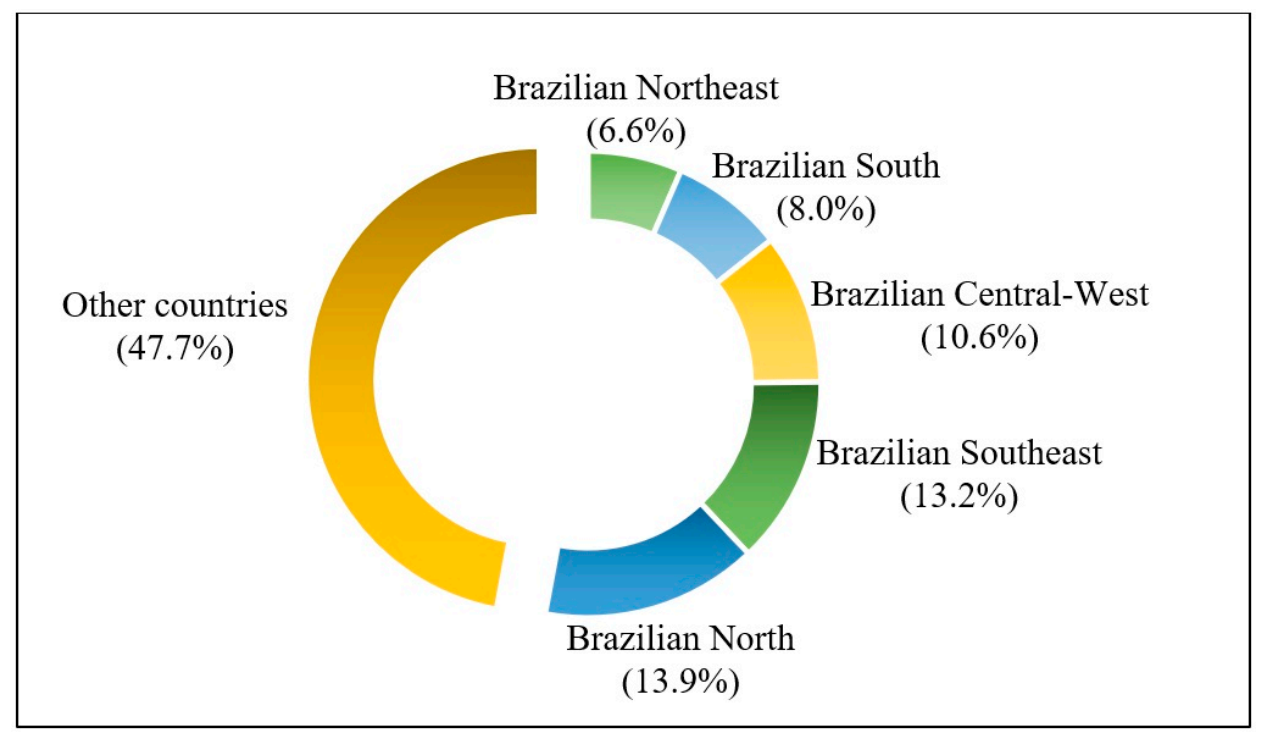

Figure 6. Location of affiliation institutions of authors of publications on non-timber forest products in Brazil until 2019.

It is important to notice that almost $48 \%$ of the affiliation institutions of authors are from outside the country. It is a remarkable fact that demonstrates the international interest in tropical biomes, especially the Amazonian region, and its mega-biodiversity and also reflects the concerns about the high rates of deforestation and fires in the last decades which put Brazil in the spotlight of global attention. Thus, international cooperation reflects concerns about development, economic relations, climate changes, and carbon stock as well as undiscovered species and their potential properties and ecological traits, therefore being those forest resources a great deal on the sustainability maintenance.

Besides, identifying which institutions are from Brazil and which are from other countries contributes to assign appropriate credit to these institutions and helps to disclose them, which could lead to creating a support network for a new joined research between institutions, especially between those who do not have good structure and the ones that have access to new technologies and funding. Therefore, by reporting institutions with the potential to carry out high-level research, the bibliometric reviews can contribute as a potential tool for facilitating the foundation of interinstitutional databases, ergo facilitating the exchange of information and experiences at local, national and international levels, both in the public or private agencies.

Figure 7 shows the distribution of publications in Brazilian territory. Evaluating Brazilian institutions, 26 of these (32.9\%) have three or more publications, being considered the main ones that publish about NTFPs in Brazil (Figure 8). It is observed that the wide distribution of these institutions throughout the Brazilian territory, in which the great majority is made up of public teaching, research, and extension institutions. The five main publishing institutions on the subject are the Universidade de São Paulo (USP) and Instituto Nacional de Pesquisas da Amazônia (INPA), in addition to the Universidade de Brasília (UNB), Universidade Federal de Santa Catarina (UFSC) and Universidade Federal do Paraná (UFPR) It should be also noted that the third main Brazilian geographic region regarding the value of NTFPs extraction is the Northeast (24\%; behind South with $29 \%$ and North with $45 \%$ ) but is the last one on national institutions of authors affiliation, in contrast with the affiliations from 
the Southeast (13.2\%) and Central-West (10.6\%), corresponding each with $1 \%$ of the NTFPs national value [9]. Such facts indicate that the research and, consequently, its generated knowledge and/or product could not be local widespread and the generated knowledge appears to have a considerable correlation with areas where there is a higher number of graduate programs in Forest Sciences and Forestry Engineering and research centers where there is better and easier access to new technologies and funding.

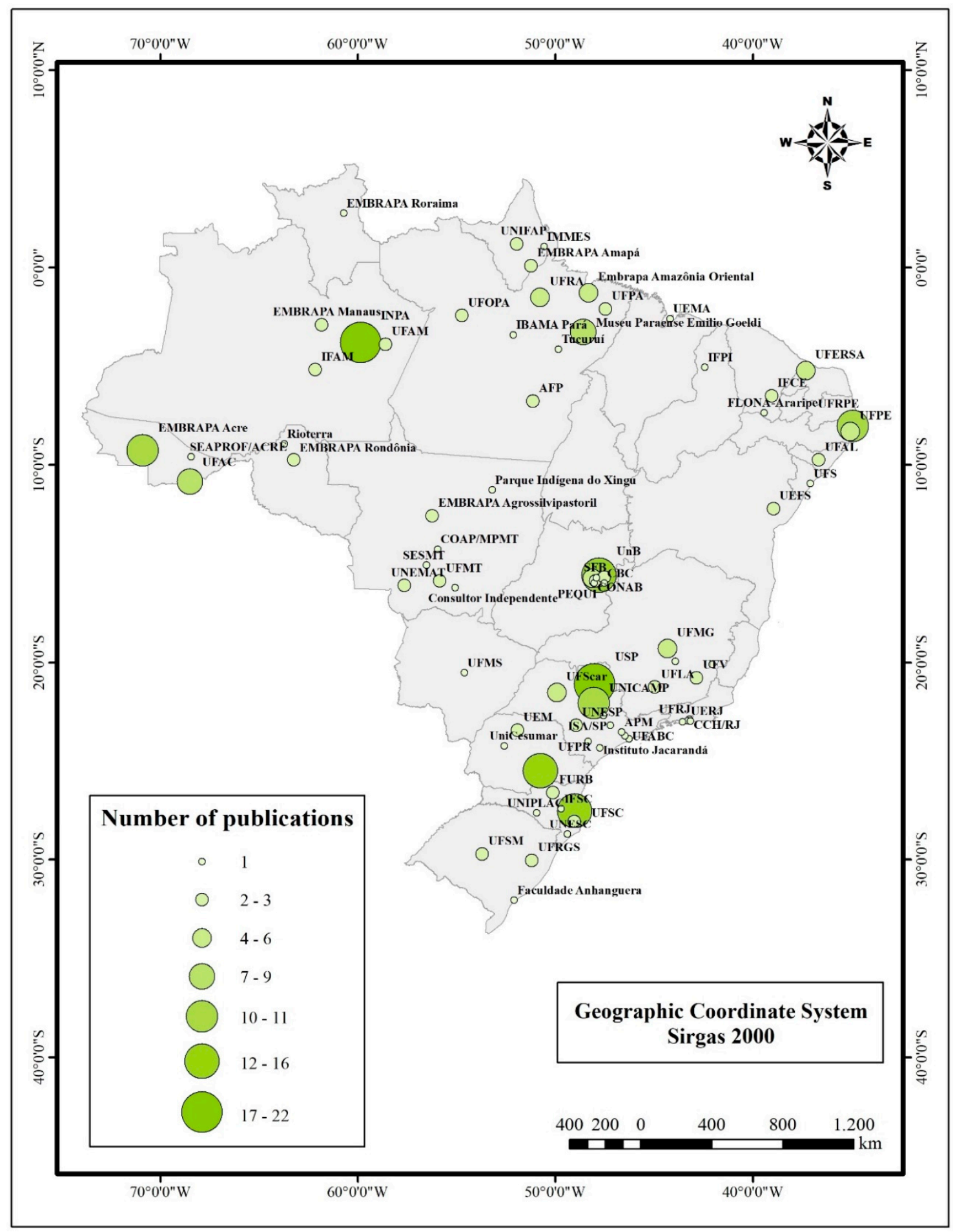

Figure 7. Distribution of publications on non-timber forest products in the Brazilian territory according to the authors' affiliation institutions. 


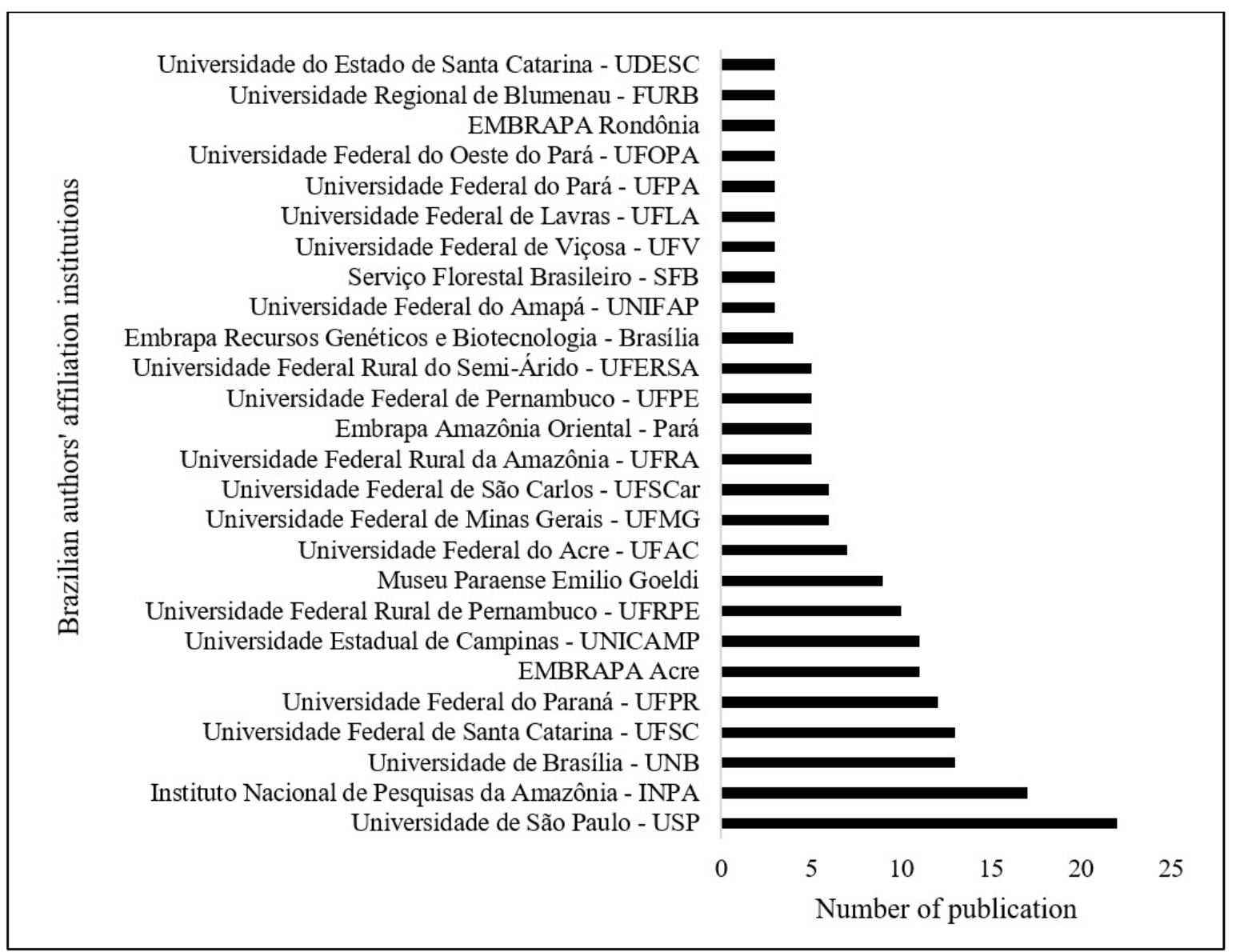

Figure 8. Brazilian affiliation institutions of prominent authors in publications on non-timber forest products in Brazil until 2019.

The availability of products for carrying out research is one of the main difficulties in generating knowledge since the biological diversity in the Brazilian territory practically takes the regions ownership some species for their exploration. This fact is important to add the evaluation by the Brazilian regions, aiming to survey the institutions that have research potential for these products and how they can contribute to the exchange of information, making their structure available with the other research institutions.

Historically, several regions have had some difficulties in acquiring the potential to have updated technologies that improve the authors' results and productivity. Thus, the highlight of the main institutions helps to identify them, both in the Brazilian territory and in other countries that are research partners. Therefore, there is an emphasis on improving research in the Northeast and increasing the volume of institutions and authors from the central region.

In all, 78 institutions and funding agencies for the evaluated publications were identified, contributing 190 times to the promotion of this research. Of these, 26 are Brazilian $(33.3 \%)$ and 52 are international $(66.7 \%)$, however, national agencies have contributed to more research $(57.4 \%)$, showing the importance of these for the development of research in Brazilian lands. Figure 9 shows 24 institutions that stood out in their contributions to published works on NTFPs in Brazil, promoting two or more researches. Together, they represent $71.6 \%$ of publications. 


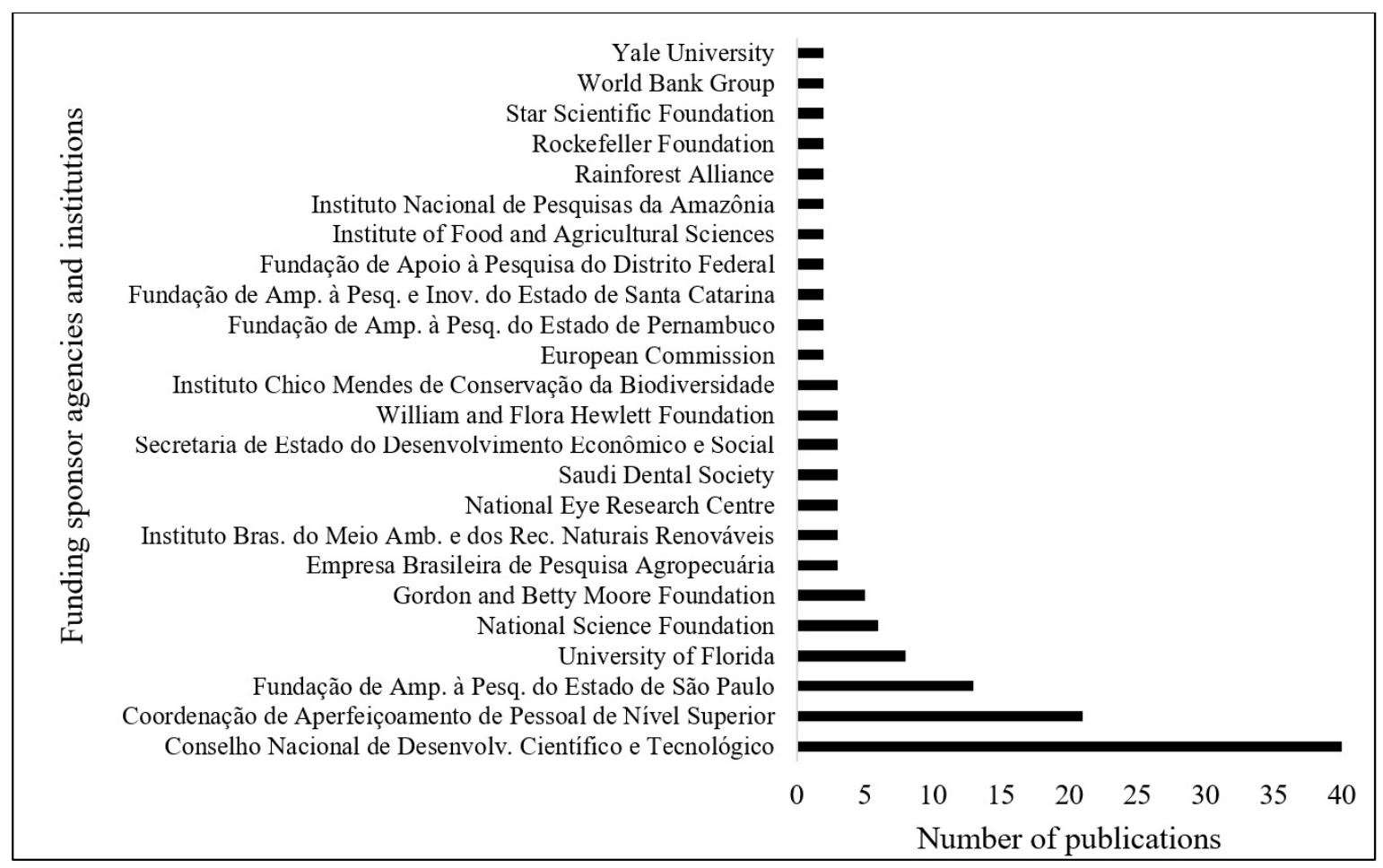

Figure 9. The number of publications sponsored by agencies and institutions that promote research on non-timber forest products in Brazil until 2019.

The three agencies that contributed most to the work were Brazilian, namely the Conselho Nacional de Desenvolvimento Científico e Tecnológico (CNPq), the Coordenação de Aperfeiçoamento de Pessoal de Nível Superior (CAPES) and the Fundação de Amparo à Pesquisa do Estado de São Paulo (FAPESP). These agencies are important for national research, as they finance teaching, researching, and extension projects at a higher level, in addition to postgraduate projects, at the masters, doctoral and postdoctoral levels. Other important national agencies for the development of research in Brazil, which are directly linked to the federal government and presented important numbers are the Empresa Brasileira de Pesquisa Agropecuária (EMBRAPA), the Instituto Brasileiro do Meio Ambiente e dos Recursos Naturais Renováveis (IBAMA), Secretaria de Estado do Desenvolvimento Econômico e Social (SEDES) and Instituto Chico Mendes de Conservação da Biodiversidade (ICMBio). As for international incentives, the institutions of the University of Florida, National Science Foundation, and Gordon and Betty Moore Foundation stand out, which mainly contribute to studies carried out in the Amazon.

It was identified that these documents were published in 87 different journals, observing that the theme is quite embraced. Of these journals, $63.2 \%$ have only one published article, the rest being shown in Figure 10. Among the 32 featured journals, $43.75 \%$ are Brazilian, showing that many researchers are publishing their articles in journals worldwide. It is observed that the highlights of publications are from Forest Ecology and Management and Economic Botany, with 30 and 13 documents, respectively, which have as their main scope the research involving the areas of Ecology, Forest Management, and Economics. This tendency to publish these subareas of agricultural sciences will be highlighted later. Among Brazilian journals, the highlights are Acta Botanica Brasilica, Ciência Florestal, Revista Árvore, and Revista Brasileira de Plantas Medicinais, which present four or more publications. 


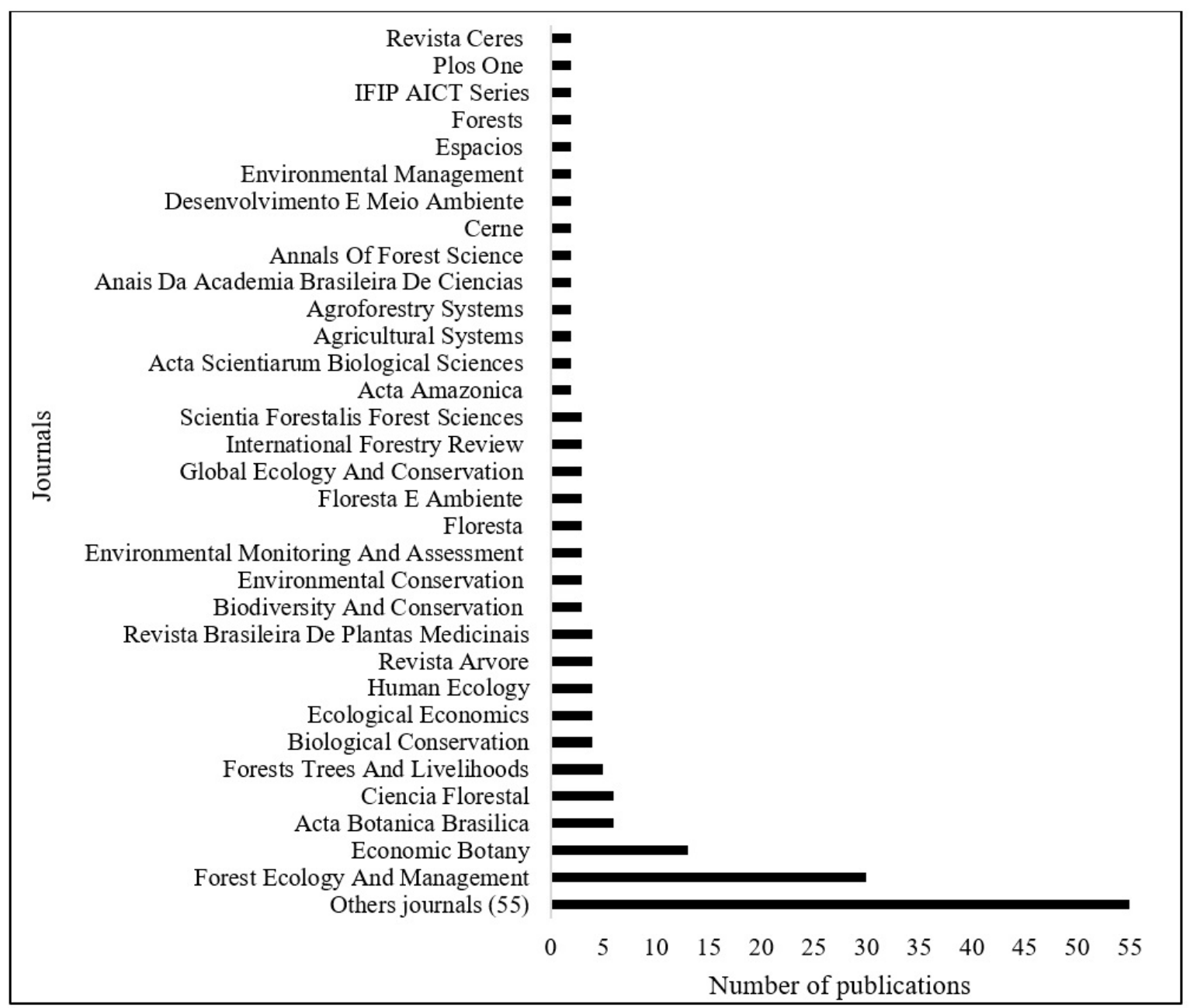

Figure 10. Periodicals for publishing documents on non-timber forest products in Brazil until 2019.

According to the Scopus classification, these publications were subdivided into 19 areas of science (Figure 11), some of which were multidisciplinary. Among the areas, the majority of publications involved Agricultural and Biological Sciences and Environmental Science. This fact is justified because they are the areas that most support the research of non-timber forest products in Brazil, according to the way of obtaining these products in natural or planted environments and the technologies that involve the preparation of co-products. Besides, another highlight is the Social Sciences area, appearing as the third that involves these publications, due to the obtaining of non-timber forest products in the country, which still comes from traditional and indigenous populations, besides being often a source of subsistence for other people [10], that end up being the object of study of these researches.

As for the areas of Forest Sciences (Table 1), it can be observed that most of the works focused on the area of Nature Conservation, covering themes on Ecology and Conservation of Forest Resources, Genetics and Fire Management, to obtain the relationship between the exploitation of resources and the impacts generated by anthropic activities. Among the 196 publications evaluated, $28.1 \%$ are multidisciplinary, reaching up to three areas of Forest Sciences in their objectives. 


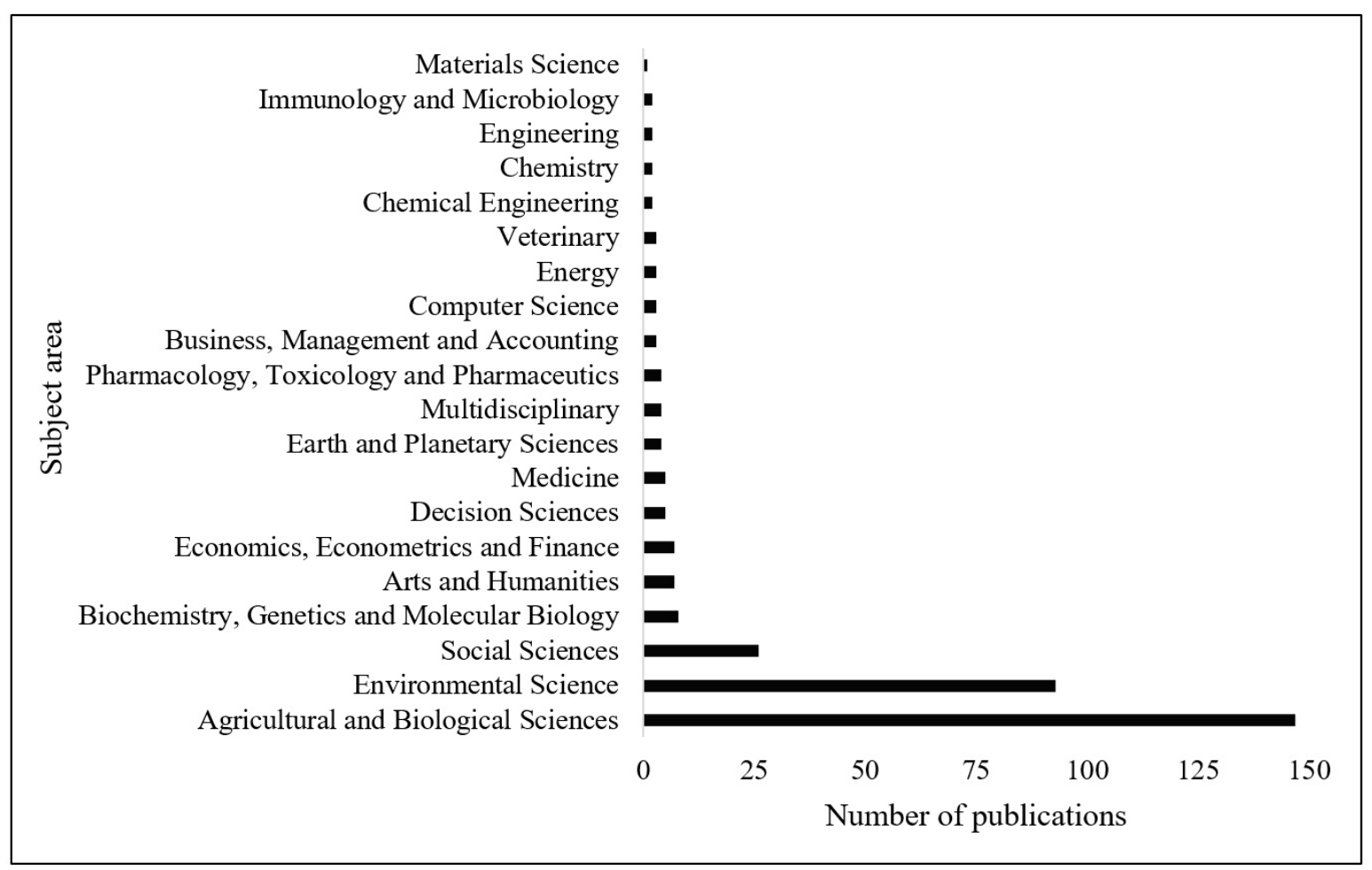

Figure 11. Publications on non-timber forest products in Brazil classified in areas of Science, according to Scopus, until 2019.

Table 1. Publications on non-timber forest products in Brazil classified in areas of Forest Sciences until 2019.

\begin{tabular}{cc}
\hline Areas of Forest Science & Publications (\%) \\
\hline Nature Conservation & 35.97 \\
Forest Economy, Administration, Legislation and Policy & 28.06 \\
Management of Native and Planted Forests & 25.30 \\
Technology and Use of Forest Products & 6.72 \\
Forestry/Silviculture & 3.95 \\
\hline
\end{tabular}

The Forest Economics, Administration, Legislation, and Policy areas also stand out, mainly trying to find a correlation between the acquisition of financial resources by NTFPs. Most of these publications involved economic evaluation of products and co-products generated by Brazilian forests, mentioning the national or international market, in addition to associating the policies and legislation that imply in the inspection and regularization of the NTFPs trade. The Forest Management area also stood out among the published surveys, mainly addressing themes for the inventory of products and co-products. In this field, a great number of researches are being developed using geotechnologies through image analysis techniques, in addition to modeling and forest biometry studies which are consolidated subjects in the Brazilian forestry area. Besides that, it is necessary to set methodologies that aim the improvement of the assesses of NTFPs manufacturing by those instruments.

Regarding the evaluated publications, the use and technology of those products are still underexplored for the main amount of the studied species. It is a consensus in Brazil that are some well-studied species, which generates a more complete database, in contrast with a significant number of species that still lack studies that could state which are the best applications and create techniques and procedures to acquire products and co-products. In the field of Technology and Use of Forest Products more groundbreaking studies could be performed aiming more accuracy and 
faster results. The use of non-destructive techniques, as Near-Infrared spectroscopy, could be the development keystone on the researches on this field.

It is observed that a large part of these works is related to activities of extraction of natural resources in native forests, given the little publication of research that involves the planting of forest species for the acquisition of NTFPs, also encouraging the development of research on Silviculture of these species, in addition to exploring new species based on their potential for using products and co-products.

\subsection{State of the Art}

From the evaluation of the publications, it was observed that the highest percentage of research was carried out in the Amazon Forest, followed by the Atlantic Forest, Cerrado, Caatinga, and Pantanal, respectively (Figure 12). In some of the records, the areas evaluated were not indicated, or even carried out at the national level, not specifying which vegetation was studied, but presenting important data on socio-economics, ecology, and the technology of the NTFPs that were the focus of the study.

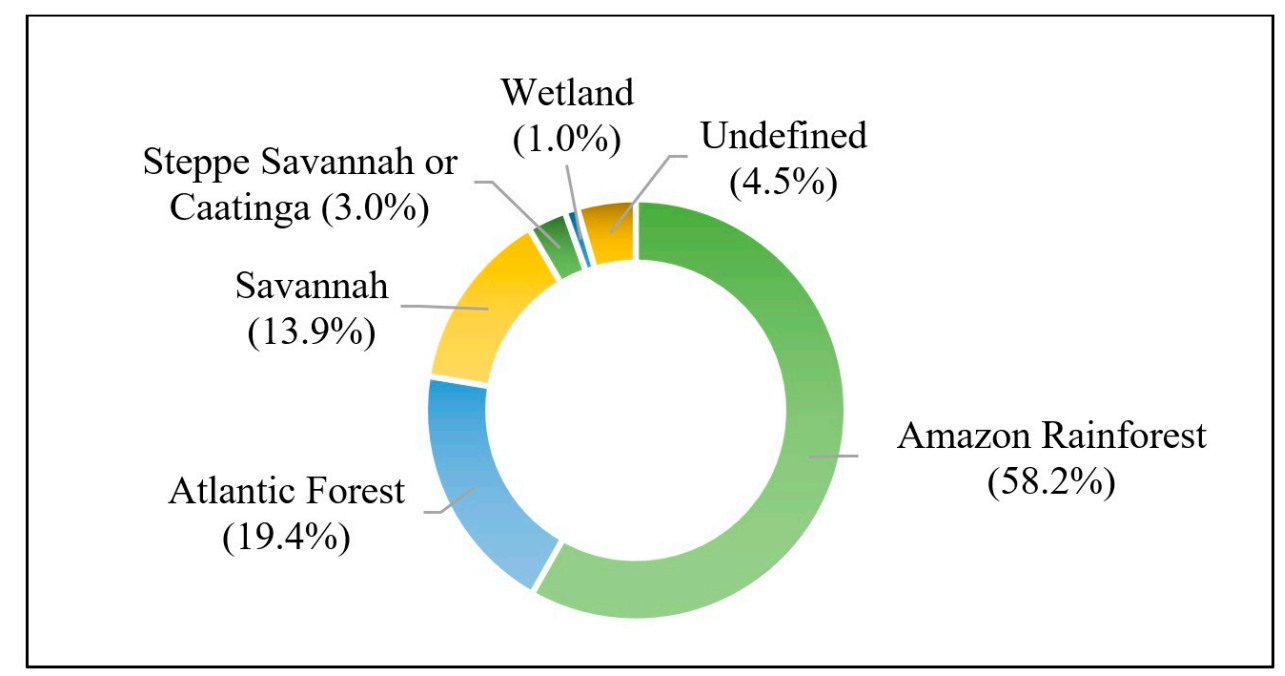

Figure 12. Publications on non-timber forest products in Brazil by Brazilian phytogeographic domains until 2019.

The Amazon Forest, as well as tropical forests as a whole, contributes significantly to the provision of ecosystem services due to its high biodiversity, generation of non-timber products, and carbon fixation [11], being considered one of the most important biomes in the world. One of the main regulations in the legislation occurs due to the management for obtaining wood, although several NTFPs stand out for the production of fruits, oils, seeds, straw, flowers, resin, and latex, in addition to other co-products used in the food, textile, chemical, and pharmaceutical industries. The Amazon forest is a biome that surpasses geopolitical limits, has a vast area, and tremendous biodiversity, hence, prompts worldwide interest and it is, consequently, the most researched biome. As the main tropical forest in the Americas, its exploitation is one of the main sources of local, regional, and national income, such attention makes it one of the major focuses of Brazilian legislation. Meanwhile, other Brazilian biomes have incipient or lack of regulatory legislation, which generates conflicts and make it difficult for a better and efficient profiteering.

The Atlantic Forest is of great importance for Brazilian forest biodiversity, and although it currently has a large area reduction, it represents a good part of the floristic composition of the Brazilian coast, mainly of the east coast of the Atlantic [12]. Despite the degradation factor, it still has significant characteristics to produce NTFPs, being widely explored in the Northeast, Southeast, and South regions of the country. To regulate the management, conservation, and the best way to monitor the use of 
environmental resources, the so-called Atlantic Forest Biome Law was instituted and, also the Brazilian Federal Law n. 11428/2006 [13], to regulate the protection and use of ecosystem biodiversity.

Historically, the exploration of chemical compounds from species such as brazilwood (Paubrasilia echinata (Lam.) Gagnon, H.C.Lima \& G.P.Lewis) has led to the development of new technologies for the exploitation of forest essences co-products. Currently, the main NTFPs obtained naturally from the Atlantic Forest areas are fruits, seeds, flowers, and the exploitation of palm trees to obtain palm hearts and straw, intended for the food industry or artisanal use.

The management of forest and savanna species has ecologically affected the recovery of these areas, a reality observed by studies carried out in the Cerrado, with an intense reduction of the area recorded for conversion to agropastoral uses. For this reason, the Brazilian Cerrado areas should have priority for studies and actions aimed at their conservation, including which species are affected by changes in land use and occupation and consequent local climate changes [14]. The main NTFPs of this biome are fruits for food, although they do not compromise the population density of seedlings for the regeneration of native forests [15]. Also, flowers stand out, traditionally widely used for ornamental purposes [16].

Although not a current discussion, there is a need to perform research on Caatinga species for better exploitation of this ecosystem, mainly due to the indiscriminate use of these forest essences to supply the region's energy demands through the burning of firewood and production of charcoal [17]. The harvest of fruits, leaves, seeds, and peels is the main source of NTFPs in the biome, being exploited by the food, chemical, and pharmaceutical industry [18,19].

Altogether, 76 species or forest genera were the main focus of the research, shown in Table 2. In all, 11 of these stand out with more than five publications that involve the technologies for their use.

The main amount of the related species is commercialized for food purposes, in addition to medicinal applications, those being the second most numerous group, followed by cosmetics and ornamental use. Juçara-palm, Brazil nut, and açaí are conventional edible species, internationally consumed, meanwhile other species like cumaru and cataia are non-conventional edible plants, which demonstrates the importance of their characterization and properties for the rightful purposes and correct management. The use of botanical products to extract some chemicals actives is a result of a global trend that aims the use of more natural and organic sources along with more social and environmentally responsible sources and manufacturing, along with an eco-friendly lifestyle both for cosmetics, food and medicinal issues. Another highlight is the multiple uses of some species which is a result of the efforts to diversify the use of forests in the country.

The extractivism activity is in retraction for almost two decades, since 2002, with one peak in 2010 and 2015, with a value of more than 1.6 billions of reais in 2018. Food is the main category of NTFPs production in Brazil with three predominant products (representing about $93 \%$ of its total value): açaí (corresponding to $46.3 \%$ of the category value), followed by erva mate (36.7\%) and Brazil nut (more than $10 \%)$. The last product has a major number of studies (34), followed by açaí (13), which is aligned with the current scenery of its commercialization. It is also important to highlight that the Brazil nut is the third NTFP with the highest value of exportation on the country in the reference year. Thus, these studies are also affirming that the literature is well oriented towards current commerce trends and demands. Therefore, products there are not currently playing major roles in the economy but has a significant number of studies, such as andiroba and pequi ( 8 each) could indicate a currently expanding in their use and a future trend $[20,21]$.

When evaluated according to the occurrence, the most researched species belong to the Amazonian environment, whose largest number of publications were on Brazil nuts and açaí, as well as copaíba, andiroba, rubber, and babassu. For the Cerrado, research on pequi, janaguba, and buriti stands out, which also occurs in the Amazon rainforest. Araucaria and palm-juçara are the main sources of NTFPs explored in the Atlantic Forest. Although none of the main featured species are found in the Caatinga, the most explored product in this biome is the cashew. Some considerations about these species are presented below. 
Table 2. Species supplying non-timber forest products surveyed in Brazil until 2019.

\begin{tabular}{|c|c|c|c|c|c|}
\hline Species & Scientific Name & $\mathbf{N}$. & Species & Scientific Name & N. \\
\hline Brazil nut & Bertholletia excelsa & 34 & Butiá & Butia purpurascens & 1 \\
\hline Açaí & Euterpe oleracea & 13 & Cauaçu & Calathea lutea & 1 \\
\hline Copaíba & Copaifera sp. & 10 & Sapucainha & Carpotroche brasiliensis & 1 \\
\hline Juçara-palm & Euterpe edulis & 9 & Copaíba 1 & Copaifera langsdorffii & 1 \\
\hline Andiroba & Carapa guianensis & 8 & Copaíba 2 & Copaifera multijuga & 1 \\
\hline Pequi & Caryocar brasiliense & 8 & Liana 2 & Desmoncus polyacanthos & 1 \\
\hline Janaguba & Himatanthus drasticus & 7 & Fava d'anta & Dimorphandra gardneriana & 1 \\
\hline Buriti & Mauritia flexuosa & 7 & Cumaru & Dipteryx odorata & 1 \\
\hline Rubber tree & Hevea brasiliensis & 6 & Cataia & Drimys brasiliensis & 1 \\
\hline Araucaria & Araucaria angustifólia & 5 & Pitanga & Eugenia uniflora & 1 \\
\hline Babassu & Attalea speciosa & 5 & Liana & Forsteronia glabrescens & 1 \\
\hline Palm's heart & Euterpe sp. & 4 & Bamboo 1 & Guadua sarcocarpa & 1 \\
\hline Titica vine & Heteropsis flexuosa & 3 & Bamboo 2 & Guadua weberbaueri & 1 \\
\hline Cashew & Anacardium occidentale & 2 & Jatobá & Hymenaea spp. & 1 \\
\hline Pequiá & Caryocar villosum & 2 & Ingá & Inga capitata & 1 \\
\hline Uxi & Endopleura uchi & 2 & Palm tree 1 & Iriartella setigera & 1 \\
\hline Açaí-da-mata & Euterpe precatória & 2 & Arumã & Ischnosiphon gracilis & 1 \\
\hline Mangaba & Hancornia speciosa & 2 & Cortiça & Kielmeyera coriacea & 1 \\
\hline Vine & Heteropsis spp. & 2 & Arnica & Lychnophora ericoides & 1 \\
\hline Vine 1 & Heteropsis macrophylla & 2 & Maçaranduba & Manilkara spp. & 1 \\
\hline Vine 2 & Heteropsis spruceana & 2 & Deer & Mazama sp. & 1 \\
\hline Vine 3 & Heteropsis steyermarkii & 2 & Canela & Nectandra grandiflora & 1 \\
\hline Vine 4 & Heteropsis tenuispadix & 2 & Palm tree 2 & Oenocarpus bacaba & 1 \\
\hline Seringueira & Hevea spp. & 2 & Palm tree 3 & Oenocarpus bataua & 1 \\
\hline Erva-mate & Ilex paraguariensis & 2 & Palm tree 4 & Oenocarpus minor & 1 \\
\hline Arumã & Ischnosiphon polyphyllus & 2 & Amapá amargo & Parahancornia fasciculata & 1 \\
\hline Samambaia-de-folha & Rumohra adiantiformis & 2 & Cipó-preto & Philodendron corcovandense & 1 \\
\hline Capim dourado & Syngonanthus nitens & 2 & Cataia/canela & Pimenta pseudocaryophyllus & 1 \\
\hline Bromeliad 1 & Aechmea nudicaulis & 1 & Papiroba & Piper gaudichaudianum & 1 \\
\hline Liana 1 & Amphilophium paniculatum & 1 & Bacuri & Platonia insignis & 1 \\
\hline Cana de aniba & Aniba canelilla & 1 & Breu & Protium sp. & 1 \\
\hline Tucuma & Astrocaryum aculeatum & 1 & Aroeira & Schinus terebinthifolius & 1 \\
\hline Murumuru & Astrocaryum murumuru & 1 & $\begin{array}{l}\text { Espinheira } \\
\text { santa }\end{array}$ & Sorocea bonplandii & 1 \\
\hline Palmeira tucumã & Astrocaryum tucuma & 1 & Esfagno & Sphagnum sp. & 1 \\
\hline Acuri & Attalea phalerata & 1 & Barbatimão & Stryphnodendron rotundifolium & 1 \\
\hline Pupunha-palm & Bactris gasipaes & 1 & Cobrina & Tabernaemontana catharinensis & 1 \\
\hline Palmeira 1 & Bactris marajá & 1 & Candombá & Vellozia sincorana & 1 \\
\hline Bromeliad 2 & Bromelia antiacantha & 1 & Bromeliad 3 & Vriesea incurvata & 1 \\
\hline
\end{tabular}

The exploitation of Brazil nuts (Bertholletia excelsa Humn. \& Bonpl.) is already consolidated in the Amazon forest economy [22]. Among the producing and exporting countries of B. excelsa, Brazil, Peru, and Bolivia stand out [23]. In Brazil, cultivation is greater in the states of Acre, Amazonas, and Pará, in the North Region, with Mato Grosso also appearing, with less expressiveness [24]. The species has historical importance as a source of food and income, in which the almond is considered a source of protein with high nutritional value [25]. In addition to fruit production, agricultural residues of the species have been used in the energy industry, since each ton of nuts generates about 1.4 tons of waste that have potential use as an energy source, through direct burning, production of activated carbon and biochar [26].

In the Amazon region, the cultivation of açaí (Euterpe oleracea Mart.) is found mainly in the state of Pará, responsible for about $60 \%$ of the national production [27]. In the North of Brazil, consumption predominantly occurs with fish and flour, in other regions its consumption occurs in conjunction with other foods or in a processed way, commonly found in the form of ice cream or pulp [28]. Studies indicate that regular consumption of açaí juice promotes improvement in HDL-c levels, antioxidant activities, and consequently contributes to cardiovascular health [29].

Copaiba (Copaifera sp.) comprises a group of endemic species in the Amazon region and despite its use for timber and ornamental production, the major use is for the production of oil, which is widely used in folk medicine as healing, antifungal, insecticide and animal supplementation [30-32]. Andiroba (Carapa guianensis Aubl.) is widely used in folk medicine because it is easily obtained from oil, 
which has a fungicidal action and helps in the process of weight loss, being used against hypertension issues, in addition to demonstrating anticonvulsant properties [32-35].

The rubber tree (Hevea brasiliensis L.) is widely cultivated in the Amazon region and is managed for the extraction of latex. The most valued product is rubber, used from the automotive industry to chemical and pharmaceutical, for this reason, a large part of forest plantations in Africa and Asia are also used to produce this crop [36].

Babassu (Attalea speciosa Mart. Ex Spreng) is found naturally in the north and northeast of Brazil, with oil as its main product, which generates babassu flour during its process [37]. Its oil is used in the production of biodiesel and animal feed, reducing feed intake without compromising growth [37-39]. Also, production is important due to the number of products and co-products generated, which can be used in handicrafts, energy generation, and organic fertilization [40].

Buriti or miriti (Mauritia flexuosa Lf) also occurs in the north and northeast of Brazil and their exploitation is important for the local culture and economy, whose main products are straw for handicrafts and fruits, which are considered the "white açaí" [41,42].

The potential of savanna regions in Brazil is due to the exploitation of fruits. Pequi (Caryocar brasiliense Cambi) is a species of high nutritional value in the Cerrado, widely used in the food, chemical, and pharmaceutical industry, presenting characteristic color, odor, and flavor [43]. The fruit has antioxidant, leishmanicidal, and antibiotic properties, besides being rich in vitamin A [44-46]. In addition to these two species, buriti and pequi, several pieces of research were carried out with janaguba (Himatanthus drasticus (Mart.) Plumel), to determine ecological standards for the management of fresh bark and latex production [47,48].

One of the main food products of the Atlantic Forest is the juçara-palm (Euterpe edulis Mart.). A tropical palm species that is considered the main supplier of palm heart of the biome, being widely explored and commercialized in the domestic market and for export and therefore there are several questions about the degradation that this activity causes due to intensive management $[49,50]$. Besides, another option for exploiting its resources is an alternative to substitute the açaí fruit to produce pulps with significant nutritional characteristics, for the South and Southeast regions [51].

In addition to the juçara palm heart, in the Atlantic Forest biome, the araucaria (Araucaria angustifolia (Bertol.) Kuntze) stands out, a conifer occurring in the South and Southeast of Brazil, which had a significant reduction in its population due to intense exploitation, caused by the quality of its wood, as well as the increase of the use of land for agricultural production [52]. Currently, due to legal barriers imposed for the exploitation of its wood, the species has been widely used for the production of pine cones, which have seeds with high nutritional value that are part of the food of the local population [53]. The pinion is considered a traditional product of Southern Brazil because the main area with Araucaria forests is in this region.

The Caatinga representative that has local and national prominence is the cashew tree (Anacardium occidentale L.), widely found in the semiarid areas of Brazil, presenting socioeconomic prominence for the exploration and cultivation for the production of pseudo fruits (cashew apple fruit) and its nuts for various purposes of the food industry [54]. The pseudo fruit has important nutritional value, however, it is still devalued when compared to the exploration of the chestnut, which represents one of the main sources of income for the Northeast region [55]. As with B. excelsa, some studies have already been carried out to better use the residues of the nutshells, either for agricultural applications or for the extraction of chemical compounds [56].

\section{Considerations and Challenges of Brazilian Legislation on Non-Timber Forest Products}

Due to the increase in legal barriers for cutting native species and changing the use and occupation of land in these areas, it was necessary to seek alternatives for the expansion of the forest products market. Consequently, over time it was possible to realize that in some cases it is more profitable to leave the forest standing and explore other products, than just the use of wood. This multiple-use 
forest approach with the addition of sustainable forest management (SFM) began its popularization in the 1990s aiming a more socially and environmentally aligned development in tropical countries [57].

NTFPs are widely used as a source of livelihood for communities surrounding the forest. Currently, the formation of cooperatives that work individually or in partnership with organizations and/or companies have offered guidance and training to the local population. Those relations are performed to achieve sustainable exploitation of forest resources, adding value to the final product, and increasing the generation of jobs. Although there is still some controversy on this matter since there is a lot of examples of positive impacts on the empowering of local communities involved on NTFPs extractions and processing such as the prevention of outmigration and preservation of cultural identities and traditional practices as opposition with internal communities disputes, price value settings and risks involving species overexploitation [58,59].

The late decades of the 20th century were marked by a rising world concerning regarding environmental issues and forest conservation and remarkable interest in tropical forests, thus, a higher number of studies were carried to learn about the main problems, market trends and logistics, wildlife ecological trends, characterization, and potential uses and also the implications and impacts on traditional populations, especially since the 1990s [60]. In the national scenario, in the 1980s there was a lot of tension in Brazil regarding the territorial use and occupation of traditional populations in the Amazon basin, especially the Amazonian rubber tappers, forcing a new look on policies and regulations [59].

Despite being widely explored in Brazil, there is still no national specific legislation to manage the extraction and commercialization of NTFPs, which makes it difficult to implement management plans. In this way, all records associated with the activity become uncertain, considering that a large part is not documented. Without regularization, it becomes more difficult to implement an ecologically viable management system, whose overexploitation can cause an imbalance in the ecosystem. Authors associate the lack of information related to the details of the processes of collection, industrialization, and commercialization of NTFPs to the seasonality and variability of their production and sale, characterizing the main obstacle to the creation of market strategies that boost the activity [6]. In addition to that, the NTFPs in Brazil has its sources in distinct biomes and each state of the federation and its municipalities have the power to instates their regulations, there is, therefore, a wide range of variations to be considered including but not limited to market logistics, cultural practices, and local communities peculiarities, resulting in a challenging and complex task to elaborate national policies and regulations that surpass generalizations.

Between 1976 and 2008, only 14 regulations including acts, edicts, and ordinances were promulgated in the country at national and state levels regarding NTFPS, usually contemplating a certain species or a set of species mainly related with overexploitation, such as the Normative Instruction n. 05/1999 (IBAMA) which regulates the exploitation and trade of palm heart and an ordinance from the Environment Ministry (MMA) n. 443/2014 that lists a significative number of endangered and vulnerable species that its NTFPs can be extracted with some restrictions and providences. Until 2008, only the Acre state had formal specific and complete regulation of their main NTFPs as a result of a joined task force. It includes technical guides on the management and harvesting of the 14 keys species and the development of legal instruments regulating the use of NTFPs [61].

In the current legislation, NTFPs are mentioned only in a generic way in the Public Forest Management Law [4], specifying sustainable production in these areas and in the Forest Code [5], which defines which products are classified as non-timber in fruits, seeds, flowers, leaves, barks, oils, resins, vines, bulbs, bamboo, and roots. The mention of NTFPs in the Forest Code is included in occasional activities or those with low environmental impact, allowing their collection for subsistence purposes and seedling production, with the proviso that they do not alter the characteristics of the native vegetation and that do not cause environmental damage in the place. Besides, it discusses the conditions, methods, and areas of collection, as well as the obligations of the manager. A Normative Instruction elaborated by the Agriculture, Livestock and Supply Ministry and the Environment 
Ministry regarding the technical standards for the obtaining of organic products originated from organic sustainable extractivism defined non-timber products as "all biological material, except for round and sawn wood, [wooden] boards, [wood] panels and wood pulp, that can be extracted from natural or modified ecosystems, and can be used for domestic or commercial purposes, or endowed of social, religious or cultural-specific significance, such as roots, mushrooms, peels, vines, leaves, flowers, fruits, seeds, exudates and fibers" [62].

Another legislation that covers the NTFPs is those related to the sociobiodiversity products (Interministerial Ordinance MDA/MDS/MMA n. 239/2009; Interministerial Ordinance MMA/MDS n. 284/2018), which is defined as "goods and services (final products, raw materials or benefits) generated from biodiversity resources, engaged in the generation of productive chains on the behalf of indigenous people and traditional communities and family-based agriculture, that promotes the maintenance and valorization of their standards and knowledge, and assures its originated rights, spawning income and promoting an increase in their life quality and habited environment" [63,64]; and its correlated programs, such as the National Plan to promote de productive chains of sociobiodiversity products and Familiar-based and Community Forest Management Federal Program.

Since 2008, the National Monetary Council (Conselho Monetário Nacional, CMN, subordinated to the Brazilian Central Bank) sets warranty prices values to some vegetal products, including a few NTFPs, and it is updated twice a year as a result of the creation of the Warranty Prices Values for the Familiar Agriculture Program (Programa de Garantia de Preços para a Agricultura Familiar, PGPAF) by the National Edict n. 5.996/2006. The first CMN Resolution regarding this matter was the n. 3.632/2008 which includes peanuts, natural rubber, cashew nuts, Brazilian nuts, carnaúba powder, juta/malva, and sisal. The most recent resolution is CMN n. 4.825/2020 that sets the values for rubber, cultivated cocoa nuts, cashew nuts, erva-mate, and sisal fiber. All those regulations can be accessed online in the Brazilian Central Bank site and the Rural Credit Manual (Manual de Crédito Rural).

Focusing on the Brazilian Amazon biome, 165 species regarding NTFPs were registered in the IBGE as explored in the area but only 20 of them have some legal ordinance present in 46 regulations (normative instructions, resolutions, acts, edicts or laws), which 14 of them are of Federal range and the others restricted to state area. The mainly part of those regulations, a total of 35 , are classified as restrictive, and only 11 approaches NTFP management [65].

As there is no law to manage the use and exploitation of these resources, the closest thing to regularization is through certification, which is an instrument of forestry policy that certifies that a product has been obtained in compliance with a sustainable production standard. In this process, the producer is subjected to an evaluation process through national and/or international certifiers, which guarantee a seal that adds value to the final product.

The certification of wood products is already well consolidated and despite serving as a basis for some situations, it cannot be applied in an integrated way for NTFPs. It was only in the early 1990s that the movement to carry out the certification of NTFPs began, hampered by factors such as the diverse nature of its components, as well as its particularities and social and ecological complexity of the products [60]. Although there is no certification model for all types of NTFPs, many standards have already been developed and are possibly applicable at the levels of organic forest management, fair trade, and quality control $[66,67]$.

Almost 6 million hectares of forests were certificate by FSC or ABNT/CERFLOR in Brazil until 2010, being the FSC the only present in the Amazon Forest with 27 Forest Management Unity (FMU) of a total of 67 , corresponding about half of the certificated area even though the main Brazilian's NTFPs come from this biome [67-69]. In 2016 the total was almost 9 million hectares and 128 FMus [60].

Some authors cite some of these already established standards, still in force today, such as ecologically responsible forest management standards (Forest Stewardship Council; FSC); organic standards that guarantee agricultural products or agroforestry production without chemical pesticides; alternatives to certify fair-trade, guaranteeing a fair sharing of profits among producers, labor rights and adequate conditions for work; guidelines that guarantee best practices for collectors, with standards 
for the appropriate handling and hygiene of the collected materials, as well as their storage and transportation; and programs to certify the quality control of products, which involve the authentication of the species and guarantee the absence of heavy metals and residues of chemical pesticides [70].

The mapping of the NTFPs production can be an instrument to recognize the species with major interest (for economic, ecosystemic, cultural, or technological purposes) and, therefore, could be used as an indicator of sector trends as well as of the shortcomings and potential. Thus, new studies and research are needed to support the creation of rules and regulations, in addition to observing the particularities of each product or native biome to properly define these laws.

\section{Conclusions}

According to this research parameters, the first publications regarding NTFPs in Brazil occurred in the early years of 1990, but the volume of publications is still incipient regarding the number of species until nowadays. This demonstrates a deficit on the Brazilian literature regarding the knowledge, characterization, properties, management, and ecological threats of numerous potential species, and when considering the high rates of the devastation of the Brazilian biomes, those pieces of information are essential for its conservation and adequate management for sustainable use. Besides that, an interesting note is that there are already some species with recognizable multiple-uses that are being commercialized as such, which is a positive point for higher aggregate value and could lead to a better forest valorization and consequently could mean a positive impact on its management and conservation.

The research on NTFPs is multidisciplinary, with emphasis on the areas of Agricultural and Biological Sciences and Environmental Science, especially focused on the Conservation of Natural Resources and Forest Management.

The relevance of the Brazilian biomes and thus their NTFPs are explicit when there is a considerable number of international institutions researching and funding studies on those matters in the last few decades, especially concerning the Amazon forest due to its rich biodiversity. The Amazon forest is also the main subject of national researches, with a good number of regional institutions proceeding researches in the area, which could lead to an easier dialogue with local and traditional communities and their environment and also the development and dissemination of local technologies. Nevertheless, there is still a small number of Amazonian species covered by those studies, and more works on their characterization, management, extraction, and manufacturing are need for better purposes and more sustainable management. On the other hand, there is a deficit in the number of researches on other Brazilian biomes, especially the savanna ones, where problems such overexploitation are layered besides the desertification process, climate, and land uses changes.

The Brazilian legislation regarding NTFPs is the major problematic detected in this study, not even the term "non-timber forest product" is defined by Federal law, even though their participation in commercial transactions are expressive. Furthermore, there is no specific general federal law regarding the extraction, use, management, and commercialization of such products, being the main laws the ones regarding a determined species or a group of species generally regarding restrictions. Thus a higher number of studies covering a higher number of potential NTFPs species and the already in use ones are required for more accurate management, use, and commercialization for the proper development for specific laws and policies with a well-constructed database and knowhow.

Author Contributions: Conceptualization, T.C.S., E.C.G.A., C.R.S. and M.P.d.R.; Methodology, T.C.S., E.C.G.A., T.R.d.S.L. and C.A.R.; Software, T.C.S. and E.C.G.A.; Validation, T.C.S., E.C.G.A., C.R.S. and M.P.d.R.; Formal Analysis, T.C.S., E.C.G.A., T.R.d.S.L. and C.A.R.; Investigation, T.C.S. and E.C.G.A.; Resources, T.C.S., E.C.G.A., T.R.d.S.L. and C.A.R.; Data Curation, T.C.S. and E.C.G.A.; Writing-Original Draft Preparation, T.C.S., E.C.G.A. and T.R.d.S.L.; Writing-Review \& Editing, T.C.S., E.C.G.A., C.R.S. and M.P.d.R.; Supervision, C.R.S. and M.P.d.R. All authors have read and agreed to the published version of the manuscript.

Funding: This study was funded in part by the Coordenação de Aperfeiçoamento de Pessoal de Nível Superior-Brasil (CAPES)-Finance Code 001; and by the Conselho Nacional de Desenvolvimento Científico e Tecnológico-Brasil (CNPq). 
Acknowledgments: This study was financed in part by the Coordenação de Aperfeiçoamento de Pessoal de Nível Superior-Brasil (CAPES)-Finance Code 001; and by the Conselho Nacional de Desenvolvimento Científico e Tecnológico-Brasil (CNPq).

Conflicts of Interest: The authors declare no conflict of interest.

\section{References}

1. Alcântara, M.S.; Duarte, A.E.; Boligon, A.A.; Campos, M.M.A.; Lucena, R.F.P.; Pinheiro, M.A.; Cruz, D.D. Effects of different levels of exploration on the ecological processes of Dimorphandra gardneriana, a tropical savanna tree. Environ. Monit. Assess. 2020, 192, 378. [CrossRef] [PubMed]

2. Muir, G.F.; Sorrenti, S.; Vantomme, P.; Vidale, E.; Masiero, M. Into the wild: Disentangling non-wood terms and definitions for improved forest statistics. Int. For. Rev. 2020, 22, 101-119. [CrossRef]

3. Sills, E.; Shanlet, P.; Paumgarten, F.; Beer, J.; Pierce, A. Evolving perspectives on non-timber forest products. In Non-Timber Forest Products in the Global Contexto, 1st ed.; Shackleton, S., Shackleton, C.M., Shanley, P., Eds.; Springer: Berlin, Germany, 2011; pp. 23-51.

4. Brasil. Lei $n^{\circ}$ 11.284, de 2 de Março de 2006. Lei de Gestão de Florestas Públicas. Dispõe Sobre a Gestão de Florestas Públicas para a Produção Sustentável; Institui, na Estrutura do Ministério do Meio Ambiente, o Serviço Florestal Brasileiro-SFB; cria o Fundo Nacional de Desenvolvimento Florestal—FNDF; Altera as Leis $n^{\circ}$ s 10.683, de 28 de Maio de 2003, 5.868, de 12 de dezembro de 1972, 9.605, de 12 de Fevereiro de 1998, 4.771, de 15 de Setembro de 1965, 6.938, de 31 de Agosto de 1981, e 6.015, de 31 de Dezembro de 1973; e dá Outras Providências; 2006. Available online: http://www.planalto.gov.br/ccivil_03/_ato2004-2006/2006/lei/111284.htm (accessed on 1 July 2020).

5. Brasil. Lei $\mathrm{n}^{\circ}$ 12.651, de 25 de Maio de 2012. Institui o NOVO código Florestal Brasileiro; 2012. Available online: http://www.planalto.gov.br/ccivil_03/_ato2011-2014/2012/lei/112651.htm (accessed on 1 July 2020).

6. Fiedler, N.C.; Soares, T.S.; Silva, G.F. Produtos florestais não madeireiros: Importância e manejo sustentável da floresta. Rev. Ciênc. Exatas Nat. 2008, 10, 263-278.

7. Sacande, M.; Parfondry, M. Non-Timber Forest Products: From Restoration to Income Generation; FAO: Rome, Italy, 2018; p. 40.

8. Silva, N.; Martins, B.; Nagy, A.; Maciel, N. Políticas públicas do Brasil para produtos florestais não madeireiros. In The Overarching Issues of the European Space: A Strategic (Re)Positioning of Environmental and Socio-Economic; Faculdade de Letras da Universidade do Porto: Porto, Portugal, 2019; pp. 255-273.

9. Brasil. Bioeconomia da Floresta: A Conjuntura da Produção Florestal Não Madeireira no Brasil; Ministério da Agricultura, Pecuária e Abastecimento—Serviço Florestal Brasileiro: Brasília, Brasil, 2019; 45p.

10. Guariguata, M.R.; Cronkleton, P.; Duchelle, A.E.; Zuidema, P.A. Revisiting the 'cornerstone of Amazonian conservation': A socioecological assessment of Brazil nut exploitation. Biodivers. Conser. 2017, 26, 2007-2027. [CrossRef]

11. Tejada, G.; Görgens, E.B.; Ovando, A.; Ometto, J.P. Mapping data gaps to estimate biomass across Brazilian Amazon forests. For. Ecosyst. 2020, 7, 1-15. [CrossRef]

12. Cunha, A.M.; Fontes, M.P.F.; Lani, J.L. Mineralogical and chemical attributes of soils from the Brazilian Atlantic Forest domain. Sci. Agric. 2019, 76, 82-92. [CrossRef]

13. Brasil. Lei $n^{\circ} 11.428$, de 22 de Dezembro de 2006. Dispõe Sobre a Utilização e Proteção da Vegetação Nativa do Bioma Mata Atlântica, e dá Outras Providências; 2006. Available online: http://www.planalto.gov.br/ ccivil_03/_Ato2004-2006/2006/Lei/L11428.htm (accessed on 1 July 2020).

14. Hidasi-Neto, J.; Joner, D.C.; Resende, F.; Monteiro, L.M.; Faleiro, F.V.; Loyola, R.D.; Cianciaruso, M.V. Climate change will drive mammal species loss and biotic homogenization in the Cerrado Biodiversity Hotspot. Perspect. Eco. Conser. 2019, 17, 57-63. [CrossRef]

15. Giroldo, A.B.; Scariot, A. Land use and management affects the demography and conservation of an intensively harvested Cerrado fruit tree species. Biol. Conserv. 2015, 191, 150-158. [CrossRef]

16. Schmidt, I.B.; Figueiredo, I.B.; Scariot, A. Ethnobotany and effects of harvesting on the population ecology of Syngonanthus nitens (Bong.) Ruhland (Eriocaulaceae), a NTFP from Jalapão Region, Central Brazil. Econ. Bot. 2007, 61, 73-85. [CrossRef]

17. Brand, M.A. Potential use of Caatinga forest biomass under sustainable management for energy generation. Cienc. Florest. 2017, 27, 117-127. [CrossRef] 
18. Melo, F.P.L. The socio-ecology of the Caatinga: Understanding how natural resource use shapes an ecosystem. In Caatinga, 1st ed.; Silva, J.M.C., Leal, I.R., Tabarelli, M., Eds.; Springer: Cham, Switzerland, 2017; pp. 369-382.

19. Lins, T.R.S.; Braz, R.L.; Silva, T.C.; Araujo, E.C.G.; Medeiros, J.X.; Reis, C.A. Tannin content of the bark and branch of Caatinga species. J. Exp. Agric. Int. 2019, 31, 1-8.

20. Instituto Brasileiro de Geografia e Estatística. Produção da Extração Vegetal e da Silvicultura—PEVS; IBGE: Rio de Janeiro, Brazil, 2018; pp. 1-8.

21. Instituto Brasileiro de Geografia e Estatística. Quantidade Produzida E Valor Da Produção Do Brasil, Das Grandes Regiões E Das Unidades Da Federação, Segundo Os Produtos Extrativos (ano de Referência: 2018); IBGE: Rio de Janeiro, Brazil, 2019.

22. Kainer, K.A.; Wadt, L.H.O.; Staudhammer, C.L. Explaining variation in Brazil nut fruit production. For. Ecol. Manag. 2007, 250, 244-255. [CrossRef]

23. Batista, A.P.B.; Scolforo, H.F.; Mello, J.M.; Guedes, M.C.; Terra, M.C.N.S.; Scalon, J.D.; Gomide, L.R.; Scolforo, P.G.V. Spatial association of fruit yield of Bertholletia excelsa Bonpl. trees in eastern Amazon. For. Ecol. Manag. 2019, 441, 99-105. [CrossRef]

24. Lorini, A.; Wobeto, C.; Rosa, C.C.B.; Hatem, T.A.; Botelho, S.C.C. Influence of packaging on the quality of Brazil nut. Acta Amazon. 2018, 48, 368-372. [CrossRef]

25. Costa, J.R.; Castro, A.B.C.; Wandelli, E.V.; Coral, S.C.T.; Souza, S.A.G.; Cook, R.L. Aspectos silviculturais da castanha-do-brasil (Bertholletia excelsa) em sistemas agroflorestais na Amazônia Central. Acta Amazon. 2009, 39, 843-850. [CrossRef]

26. Leandro, R.I.M.; Abreu, J.J.C.; Martins, C.S.; Santos, I.S.; Bianchi, M.L.; Nobre, J.R.C. Elementary, chemical and energy characteristics of Brazil nuts waste (Bertholletia excelsa) in the state of Para. Floresta Ambiente 2019, 26, 1-6. [CrossRef]

27. Moraes, J.R.; Rolim, G.S.; Martorano, L.G.; Aparecido, L.E.O.; Oliveira, M.S.; Farias Neto, J.T. Agrometeorological models to forecast açaí (Euterpe oleracea Mart.) yield in the Eastern Amazon. J. Sci. Food Agric. 2020, 100, 1558-1569. [CrossRef]

28. Barbosa, P.O.; Souza, M.O.; Pala, D.; Freitas, R.N. Açaí (Euterpe oleracea Martius) as an antioxidant. In Pathology: Oxidative Stress and Dietary Antioxidants, 1st ed.; Peedy, V.R., Ed.; Academic Press: Cambridge, MA, USA, 2020; pp. 403-425.

29. Liz, S.; Cardoso, A.L.; Copetti, C.L.K.; Hinnig, P.F.; Vieira, F.G.K.; Silva, E.L.; Schulz, M.; Fett, R.; Micke, G.A.; Di Pietro, P.F. Açaí (Euterpe oleracea Mart.) and juçara (Euterpe edulis Mart.) juices improved HDL-c levels and antioxidant defense of healthy adults in a 4-week randomized cross-over study. Clin. Nutr. 2020, 55. in press.

30. Hanna, A.C.S.; Cruz, F.G.G.; Rufino, J.P.F.; Tanaka, E.S.; Chagas, E.O.M.; Dos Santos, J.B. Bioefficacy of the copaiba oil (Copaifera sp.) in diets of laying hens in the second production cycle in humid tropical climate. Int. J. Poult. Sci. 2013, 12, 647-652.

31. Nogueira, E.O.; Novaes, A.S.M.; Sanchez, C.M.S.; Andrade, C.M.; Da Silva, M.F.A. Avaliação do efeito do óleo-resina de copaíba (Copaifera sp.) na proliferação celular in vitro. Braz. J. Vet. Res. Anim. Sci. 2012, 49, 293-300. [CrossRef]

32. Prophiro, J.S.; Silva, M.A.N.; Kanis, L.A.; Silva, B.M.; Duque-Luna, J.E.; Silva, O.S. Evaluation of time toxicity, residual effect, and growth-inhibiting property of Carapa guianensis and Copaifera sp. in Aedes Aegypti. Parasitol. Res. 2012, 110, 713-719. [CrossRef] [PubMed]

33. Klimas, C.A.; Kainer, K.A.; Wadt, L.H.O. The economic value of sustainable seed and timber harvests of multi-use species: An example using Carapa guianensis. For. Ecol. Manag. 2012, 268, 81-91. [CrossRef]

34. Nardi, M.; Lira-Guedes, A.C.; Cunha, H.F.A.; Guedes, M.C.; Mustin, K.; Gomes, S.C.P. Artisanal extraction and traditional knowledge associated with medicinal use of crabwood oil (Carapa guianensis Aublet.) in a Peri-Urban Várzea Environment in the Amazon Estuary. Evid. Based Complementary Altern. Med. 2016, 2016, 1-12. [CrossRef] [PubMed]

35. Sousa, S.F.; Paes, J.B.; Arantes, M.D.C.; Lopez, Y.M.; Brocco, V.F. Análise Física e avaliação do efeito antifúngico dos óleos de andiroba, copaíba e pinhão-manso. Floresta 2018, 48, 153-162. [CrossRef]

36. Oghenekaro, A.O.; Kovalchuk, A.; Raffaello, T.; Camarero, S.; Gressler, M.; Henrissat, B.; Lee, J.; Liu, M.; Martínez, A.T.; Miettinen, O.; et al. Genome sequencing of Rigidoporus microporus provides insights on genes important for wood decay, latex tolerance and interspecific fungal interactions. Sci. Rep. 2020, 10, 1-15. [CrossRef] [PubMed] 
37. Araruna, F.B.; Araruna, F.O.S.; Pereira, L.P.L.A.; Brito, M.C.A.; Quelemes, P.V.; Araújo-Nobre, A.R.; Oliveira, T.M.; Silva, D.A.; Leite, J.R.S.A.; Coutinho, D.F.; et al. Green syntheses of silver nanoparticles using babassu mesocarp starch (Attalea speciosa Mart. ex Spreng.) and their antimicrobial applications. Environ. Nanotechnol. Monit. Manag. 2020, 13, 100281.

38. Figueredo, I.M.; Rios, M.A.S.; Cavalcante, C.L.; Luna, F.M.T. Effects of amine and phenolic based antioxidants on the stability of babassu biodiesel using rancimat and differential scanning calorimetry techniques. Ind. Eng. Chem. Res. 2020, 59, 18-24. [CrossRef]

39. Parente, M.O.M.; Rocha, K.S.; Bessa, R.J.B.; Parente, H.N.; Zanine, A.M.; Machado, N.A.F.; Lourenço Júnior, J.B.; Bezerra, L.R.; Landim, A.V.; Alves, S.P. Effects of the dietary inclusion of babassu oil or buriti oil on lamb performance, meat quality and fatty acid composition. Meat Sci. 2020, 160, 107971. [CrossRef]

40. Melo, E.; Michels, F.; Arakaki, D.; Lima, N.; Gonçalves, D.; Cavalheiro, L.; Oliveira, L.; Caires, A.; Hiane, P.; Nascimento, V. First study on the oxidative stability and elemental analysis of babassu (Attalea speciosa) edible oil produced in Brazil using a domestic extraction machine. Molecules 2019, 24, 4235. [CrossRef]

41. Santos, R.S.; Coelho-Ferreira, M. Miriti artifacts (Mauritia flexuosa L. f.) in Abaetetuba, Para State, Brazil: From production to marketing. Bol. Mus. Para. Emilio Goeldi Cienc. Hum. 2011, 6, 559-571. [CrossRef]

42. Sousa, F.F.; Vieira-Da-Silva, C.; Barros, F.B. The (in)visible market of miriti (Mauritia flexuosa L.f.) fruits, the "winter açai", in Amazonian riverine communities of Abaetetuba, Northern Brazil. Glob. Ecol. Conserv. 2018, 14, 1-12. [CrossRef]

43. Bezerra, N.K.M.S.; Barros, T.L.; Coelho, N.P.M.F. A ação do óleo de pequi (Caryocar brasiliense) no processo cicatricial de lesões cutâneas em ratos. Rev. Bras. Plants Med. 2015, 17, 875-880. [CrossRef]

44. Baptista, A.; Gonçalves, R.V.; Bressan, J.; Pelúzio, M.C.G. Antioxidant and antimicrobial activities of crude extracts and fractions of cashew (Anacardium occidentale L.), cajui (Anacardium microcarpum), and pequi (Caryocar brasiliense C.): A systematic review. Oxid. Med. Cell. Longev. 2018, 2018, 1-13. [CrossRef] [PubMed]

45. Oliveira, T.S.; Thomaz, D.V.; Neri, H.F.S.; Cerqueira, L.B.; Garcia, L.F.; Gil, H.P.V.; Pontarolo, R.; Campos, F.R. Neuroprotective effect of Caryocar brasiliense Camb. leaves is associated with anticholinesterase and antioxidant properties. Oxid. Med. Cell. Longev. 2018, 2018, 1-12. [CrossRef]

46. Tomiotto-Pellissier, F.; Alves, D.R.; Miranda-Sapla, M.M.; Morais, S.M.; Assolini, J.P.; Bortoleti, B.T.S.; Gonçalves, M.D.; Cataneo, A.H.D.; Kian, D.; Madeira, T.; et al. Caryocar coriaceum extracts exert leishmanicidal effect acting in promastigote forms by apoptosis-like mechanism and intracellular amastigotes by Nrf2/HO-1/ferritin dependent response and iron depletion: Leishmanicidal effect of Caryocar coriaceum leaf exracts. Biomed. Pharmacother. 2018, 98, 662-672. [CrossRef]

47. Baldauf, C.; Ciampi-Guillardi, M.; dos Santos, F.A.M.; de Souza, A.P.; Sebbenn, A.M. Tapping latex and alleles? The impacts of latex and bark harvesting on the genetic diversity of Himatanthus drasticus (Apocynaceae). For. Ecol. Manag. 2013, 310, 434-441. [CrossRef]

48. Baldauf, C.; Corrêa, C.E.; Ferreira, R.C.; dos Santos, F.A.M. Assessing the effects of natural and anthropogenic drivers on the demography of Himatanthus drasticus (Apocynaceae): Implications for sustainable management. For. Ecol. Manag. 2015, 354, 177-184. [CrossRef]

49. Muler, A.E.; Rother, D.C.; Brancalion, P.S.; Naves, R.P.; Rodrigues, R.R.; Pizo, M.A. Can overharvesting of a non-timber-forest-product change the regeneration dynamics of a tropical rainforest? The case study of Euterpe edulis. For. Ecol. Manag. 2014, 324, 117-125. [CrossRef]

50. Silva, J.Z.; Reis, M.S. Consumption of Euterpe edulis fruit by wildlife: Implications for conservation and management of the Southern Brazilian Atlantic Forest. An. Acad. Bras. Ciênc. 2019, 91, 1-20. [CrossRef]

51. Trevisan, A.C.D.; Fantini, A.C.; Schmitt-Filho, A.L.; Farley, J. Market for Amazonian açaí (Euterpe oleraceae) stimulates pulp production from Atlantic Forest juçara berries (Euterpe edulis). Agroecol. Sustain. Food Syst. 2015, 39, 762-781. [CrossRef]

52. Olguin, F.Y.; Moretti, A.P.; Pinazo, M.A.; Graciano, C. Morpho-physiological acclimation to canopy coverage of Araucaria angustifolia during the establishment in the atlantic forest, Argentina. Bosque 2019, 40, 323-333. [CrossRef]

53. Reis, M.S.; Ladio, A.; Peroni, N. Landscapes with Araucaria in South America: Evidence for a cultural dimension. Ecol. Soc. 2014, 19, 43. [CrossRef]

54. Arinzechukwu, C.S.; Nkama, I. Production and quality evaluation of fruit bars from banana (Musa sapientum) and cashew (Anacardium occidentale) apple fruit blends. Asian Food Sci. J. 2019, 10, 1-16. [CrossRef] 
55. Palei, S.; Dasmohapatra, R.; Samal, S.; Rout, G.R. Cashew nut (Anacardium occidentale L.) breeding strategies. In Advances in Plant Breeding Strategies: Nut and Beverage Crops, 1st ed.; Springer: New York, NY, USA, 2019; pp. 77-104.

56. Kyei, S.K.; Akaranta, O.; Darko, G.; Chukwu, U.J. Extraction, characterization and application of cashew nut shell liquid from cashew nut shells. Chem. Sci. Int. J. 2019, 28, 1-10. [CrossRef]

57. Guariguata, M.R.; García-Fernández, C.; Sheil, D.; Nasi, R.; Herrero-Jauregui, C.; Cronkleton, P.; Ingram, V. Compatibility of timber and non-timber forest product management in natural tropical forests: Perspectives, challenges, and opportunities. For. Ecol. Manag. 2010, 259, 237-245. [CrossRef]

58. Morsello, C. Company-community non-timber forest product deals in the Brazilian Amazon: A review of opportunities and problems. For. Policy Econ. 2006, 8, 485-494. [CrossRef]

59. Rizek, M.B.; Morsello, C. Impacts of trade in non-timber forest products on cooperation among Caboclo households of the Brazilian Amazon. Hum. Ecol. Interdiscip. J. 2012, 40, 707-719. [CrossRef]

60. Da Silva, A.P.M.; Marques, H.R.; Sambuichi, R.H.R. (Eds.) Contribuição da certificação de florestas para o cumprimento da legislação florestal no Brasil. In Mudanças no Código Florestal Brasileiro: Desafios Para a Implementação da Nova Lei; IPEA: Rio de Janeiro, Brazil, 2016; pp. 327-345.

61. Kluppel, M.P.; Ferreira, J.C.P.; Chaves, J.H.; Hummel, A.C. Case study A: In search of regulations to promote the sustainable use of NTFPs in Brazil. In Wild Product Governance: Finding Policies that Work for Non-Timber Forest Products; Laird, S.A., McLain, R.J., Wynberg, R.P., Eds.; Earthscan: London, UK, 2010; pp. 43-52.

62. Brasil. Instrução Normativa Conjunta $n^{\circ}$ 17, de 28 de Maio de 2009, Ministro de Estado da Agricultura, Pecuária e Abastecimento e o Ministro de Estado do Meio Ambiente. 2009. Available online: https://www.gov.br/agricultura/pt-br/assuntos/sustentabilidade/organicos/legislacao/portugues/instrucaonormativa-conjunta-mapa-mma-no-17-de-28-de-maio-de-2009-extrativismo-sustentavel-organico.pdf/ view (accessed on 1 July 2020).

63. Brasil. Ministérios do Meio Ambiente e do Desenvolvimento Agrário. Programa Federal de Manejo Florestal Comunitário e Familiar-PMCF; Ministério do Meio Ambiente, Ministério do Desenvolvimento Agrário: Brasília, Brasil, 2009.

64. Brasil. Ministério do Desenvolvimento Agrário; Ministério do Meio Ambiente; Ministério do Desenvolvimento Social e Combate a Fome. Plano Nacional de Promoção Dascadeias de Produtos da Sociobiodiversidade; Ministério Do Desenvolvimento Agrário-Mda; Ministério Do Meio Ambiente-Mma; Ministério Do Desenvolvimento Social E Combate À Fome-Mds: Brasília, Brasil, 2009; 21p.

65. Soares, R.A. Normas Legais Regulamentadoras da Exploração de Produtos Florestais do Bioma Amazônia; Monografia, Universidade Federal Rural do Rio de Janeiro: Seropédica, Brazil, 2014.

66. Shanley, P.; Pierce, A.; Laird, S. Além da Madeira: A Certificação de Produtos Florestais Não-Madeireiros; Centro de Pesquisa Florestal Internacional (CIFOR): Bongor, Indonésia, 2006; p. 153.

67. Basso, V.M.; Jacovine, L.A.G.; Alves, R.A.; Vieira, S.L.P. Influência da certificação florestal no cumprimento da legislação ambiental e trabalhista na região amazônica. Acta Amazon. 2011, 41, 69-76. [CrossRef]

68. FSC. Forest Stewardship Council. Global FSC Certificates: Type and Distribution. January 2010. Available online: http://www.fsc.org/fileadmin/web-data/public/document_center/powerpoints_graphs/facts_figures/ Global-FSC (accessed on 1 July 2020).

69. INMETRO. National Institute of Metrology, Standardization and Industrial Quality. ABNT/CERFLOR. Certified Companies. Available online: http://www.inmetro.gov.br/qualidade/cerflor_empresas.asp (accessed on 1 July 2020).

70. Pierce, A.R.; Laird, S.A. In search of comprehensive standards for non-timber forest products in botanicals trade. Int. For. Rev. 2003, 5, 138-147. [CrossRef]

(C) 2020 by the authors. Licensee MDPI, Basel, Switzerland. This article is an open access article distributed under the terms and conditions of the Creative Commons Attribution (CC BY) license (http://creativecommons.org/licenses/by/4.0/). 